\title{
Rare Earth Metal-Based Intermetallics Formation in Al-Cu-Mg and Al-Si-Cu-Mg Alloys: A Metallographic Study
}

\author{
A. M. Samuel, ${ }^{1}$ E. M. Elgallad, ${ }^{1}$ M. G. Mahmoud, ${ }^{1}$ H. W. Doty, ${ }^{2}$ S. Valtierra, ${ }^{3}$ \\ and F. H. Samuel $\mathbb{D}^{1}$ \\ ${ }^{1}$ Université du Québec à Chicoutimi, Chicoutimi, QC, Canada \\ ${ }^{2}$ General Motors, Materials Engineering, 823 Joslyn Avenue, Pontiac, MI 48340, USA \\ ${ }^{3}$ Nemak, S.A., P.O. Box 100, 66000 Garcia, NL, Mexico \\ Correspondence should be addressed to F. H. Samuel; fhsamuel@uqac.ca
}

Received 5 September 2017; Revised 6 November 2017; Accepted 28 November 2017; Published 18 March 2018

Academic Editor: Yee-wen Yen

Copyright (C) 2018 A. M. Samuel et al. This is an open access article distributed under the Creative Commons Attribution License, which permits unrestricted use, distribution, and reproduction in any medium, provided the original work is properly cited.

This study was conducted on $\mathrm{Al}-\mathrm{Cu}-\mathrm{Mg}$ and $\mathrm{Al}-\mathrm{Si}-\mathrm{Cu}-\mathrm{Mg}$ alloys containing either 5\%La or 5\%Ce. Two levels of Ti addition were examined, i.e., $0.05 \%$ and $0.15 \%$. Thermal analysis was the only technique used to obtain castings, from which samples were then sectioned for metallographic examination. Based on the results obtained, the following points may be highlighted. Addition of a fairly large amount of RE metals ( $\mathrm{La}$ or $\mathrm{Ce}$ ) leads to the appearance of several peaks in the solidification curve between the precipitation of the primary $\alpha$ - $\mathrm{Al}$ phase and the $\left(\mathrm{Al}-\mathrm{Al}_{2} \mathrm{Cu}\right)$ eutectic reaction. Although a significant drop in the eutectic temperature is caused by the addition of $5 \% \mathrm{La}$ or $\mathrm{Ce}$, the corresponding modification of the eutectic Si is marginal. Two main types of intermetallics were documented: a gray phase in the form of sludge with a fixed composition and a white phase in the shape of thin platelets. Due to the high affinity of $\mathrm{RE}$ to react with $\mathrm{Si}, \mathrm{Fe}$, and $\mathrm{Cu}$, several compositions were obtained explaining the observed multiple peaks in the solidification curve. Judging by the morphology of the gray phase, it is assumed that this phase is precipitated in the liquid state and acts as a nucleation site for the white phase. Lanthanum and Ce can substitute each other.

\section{Introduction}

The effect of trace Ce additions on the microstructure and mechanical properties of $\mathrm{A} 356$ ( $\mathrm{Al}-7 \mathrm{Si}-0.35 \mathrm{Mg}$ ) aluminum alloys was analyzed by Tsai et al. [1]. Their results show that two kinds of intermetallic compounds are formed, namely, $\mathrm{Ce}-23 \% \mathrm{Al}-22 \% \mathrm{Si}$ and $\mathrm{Al}-17 \% \mathrm{Ce}-12 \% \mathrm{Ti}-2 \% \mathrm{Si}-2 \% \mathrm{Mg}$ phases (percentages here and elsewhere are in wt.\%). The thermal analysis data reveal that there is no direct relationship between the eutectic growth temperature and the silicon morphology/modification rating $[2,3]$. In another study on the effect of rare earth elements' addition on microstructures and mechanical properties of A356 alloy, Tsai et al. [4] observed the precipitation of AlTiLa(Ce)Mg and $\mathrm{AlSiLa}(\mathrm{Ce})$ phases.

Intermetallic phases in nonmodified and $\mathrm{Sr}$-modified $\mathrm{Al}-\mathrm{Si}$ cast alloys containing mischmetal (MM) were investigated by Elsebaie et al. [5] who reported the formation of two distinct intermetallic phases at high solidification rate with the addition of $6 \mathrm{wt} . \%$ MM to A356.2 alloy: (i) a grey sludge phase containing $\mathrm{Ti}$ with a high $\mathrm{Ce} / \mathrm{La}$ ratio $(3: 4: 1)$ and low Mg content (0.26 wt.\%), and (ii) a white spherical phase with a low $\mathrm{Ce} / \mathrm{La}$ ratio $(1: 32: 1)$ with $\mathrm{Sr}$ content of $1.5 \mathrm{wt} . \%$ and $0.4 \mathrm{wt} . \% \mathrm{Mg}$. This white spherical phase was also observed at low solidification rate, having the same chemical composition but exhibiting larger sized particles. At low solidification rate, a white Chinese script phase, $\mathrm{Al}_{2} \mathrm{MMSi}_{2}$, is formed with an addition of $6 \mathrm{wt} . \%$ of MM with a low $\mathrm{Ce} / \mathrm{La}$ ratio $(1: 5: 1)$ associated with $0.26 \mathrm{wt} . \% \mathrm{Mg}$ content.

Effect of Ce addition on the microstructure and mechanical properties of $\mathrm{Al}-20 \% \mathrm{Si}$ alloy was investigated by Joy Yii et al. [6]. The results show that addition of 0.46 to $2.24 \mathrm{wt} . \%$ of Ce led to the formation of fine cells consisting of a mixture of eutectic Si particles and intermetallic $\mathrm{Al}_{3} \mathrm{Ce}$ and $\mathrm{CeAl}_{1.2} \mathrm{Si}_{0.8}$ phases in the $\mathrm{Al}$ matrix. In $\mathrm{Al}-17 \% \mathrm{Si}$ alloys, La begins to form intermetallics when its concentration exceeds $1 \mathrm{wt} . \%$. The La-rich phase could be represented as $\mathrm{AlSi}_{2} \mathrm{La}_{2}$ [7]. Differential thermal analysis (DTA) was 
TABLE 1: Chemical composition of the two base alloys used in the present work.

\begin{tabular}{|c|c|c|c|c|c|c|c|c|c|c|c|c|}
\hline \multirow{2}{*}{ Alloy code } & \multicolumn{12}{|c|}{ Element (wt.\%) } \\
\hline & $\mathrm{Cu}$ & $\mathrm{Si}$ & $\mathrm{Mg}$ & $\mathrm{Fe}$ & $\mathrm{Mn}$ & $\mathrm{Ti}$ & $\mathrm{Zr}$ & $\mathrm{V}$ & $\mathrm{Ni}$ & $\mathrm{Sr}$ & $\mathrm{La}$ & $\mathrm{Cr}$ \\
\hline B0 & 2.40 & 1.20 & 0.40 & 0.40 & 0.60 & $<0.05$ & 0.00 & 0.00 & 0.00 & 0.00 & 0.00 & 0.00 \\
\hline D0 & 2.40 & 8.00 & 0.40 & 0.40 & 0.60 & $<0.05$ & 0.00 & 0.00 & 0.00 & 0.00 & 0.00 & 0.00 \\
\hline
\end{tabular}

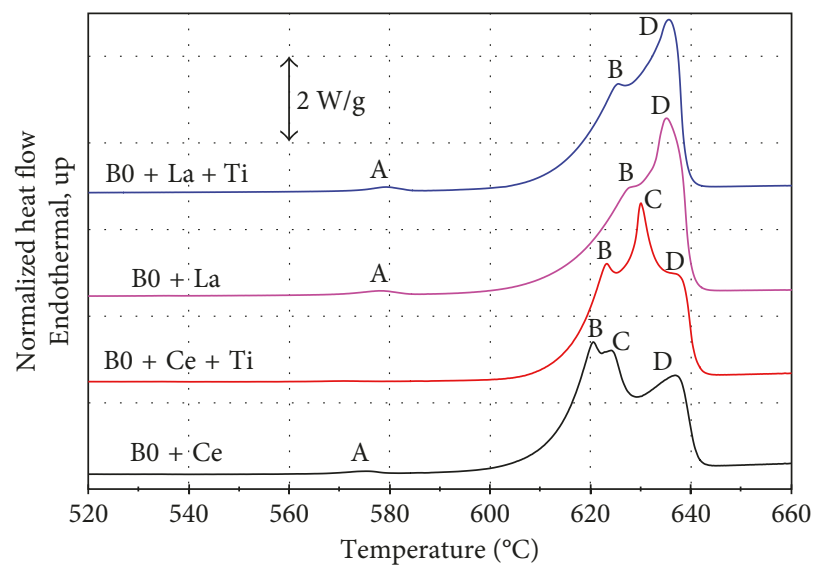

(a)

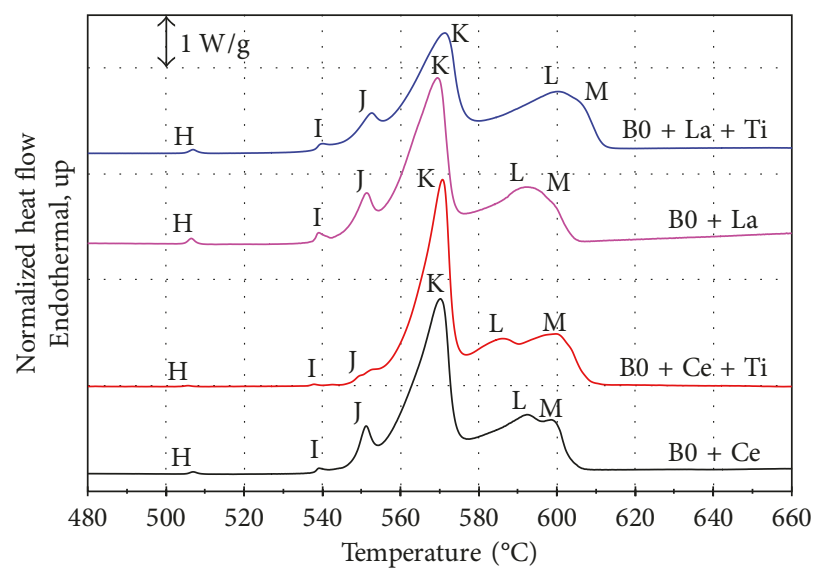

(c)

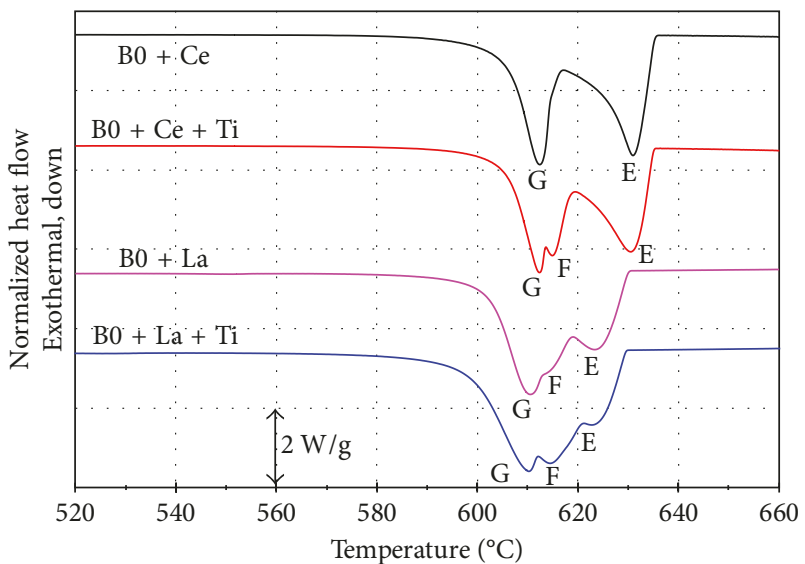

(b)

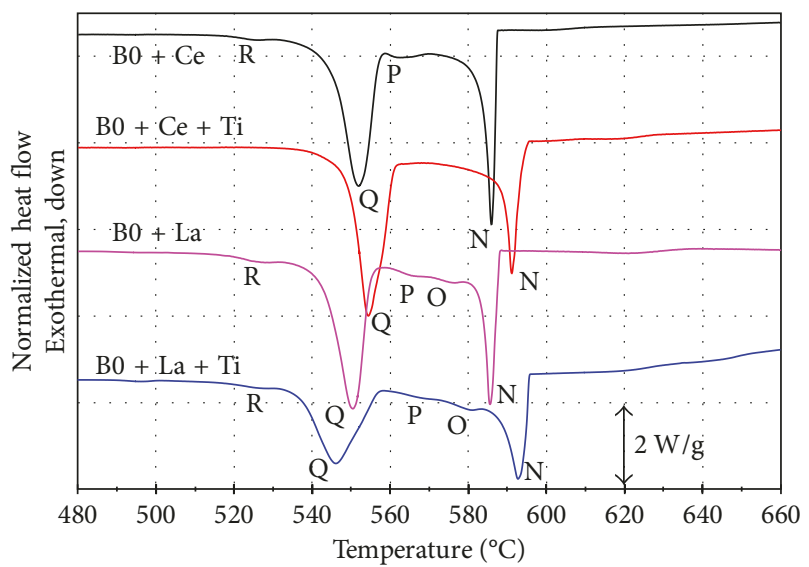

(d)

FIGURE 1: DSC heating and cooling curves of B0-based ( $\mathrm{a}$ and b) and D0-based ( $\mathrm{c}$ and $\mathrm{d}$ ) alloys.

carried out by Hosseinifar [8] on two alloys with the compositions $\mathrm{Al}-20.1 \mathrm{wt} \% \mathrm{La}-19.9 \mathrm{wt} . \% \mathrm{Mg}$ and $\mathrm{Al}-15.07 \mathrm{wt} . \%$ $\mathrm{La}-14.93 \mathrm{wt} . \% \mathrm{Mg}$; he reported on the precipitation of $\mathrm{Al}_{11} \mathrm{La}_{3}$ at $458.5^{\circ} \mathrm{C}, \mathrm{Al}_{3} \mathrm{La}$ at $554.5^{\circ} \mathrm{C}$, and $\mathrm{AlLa}$ at $521^{\circ} \mathrm{C}$.

According to Bäckerud et al. [9], the onset of different solidification reactions can be determined with the aid of thermal analyses. The crudest interpretation of the phenomena taking place can be obtained by direct observation of the temperature-time curve, as most reactions are exothermic and result in the reduction in the cooling rate or, in some cases, can result in the increase in temperature due to recalescence [9-11]. These analyses can be conducted by inserting either one or more thermocouples in the mold containing the solidifying metal. Differences in temperature can be detected between different thermocouples, or the readings from one of these devices can be derived as a function of time to evaluate the time and temperature at which the reactions take place [12-14].

The present study was undertaken to investigate precipitation of intermetallics in $\mathrm{Al}-2 \% \mathrm{Cu}-0.5 \% \mathrm{Mg}$ and $\mathrm{Al}-8 \%$ $\mathrm{Si}-2 \% \mathrm{Cu}-0.5 \% \mathrm{Mg}$ alloys containing $5 \% \mathrm{La}$ or Ce using the thermal analysis technique as the main tool (solidification rate was approximately $0.8^{\circ} \mathrm{C} / \mathrm{s}$ ). Samples sectioned from the thermal analysis castings were used for examining the microstructures. Phases were identified using an electron probe microanalyzer equipped with energy dispersive X-ray spectroscopic (EDS) and wavelength dispersive spectroscopic (WDS) facilities.

\section{Experimental Procedure}

The alloys used in this study were supplied in the form of $12.5 \mathrm{~kg}$ ingots. The chemical composition of the base alloy 


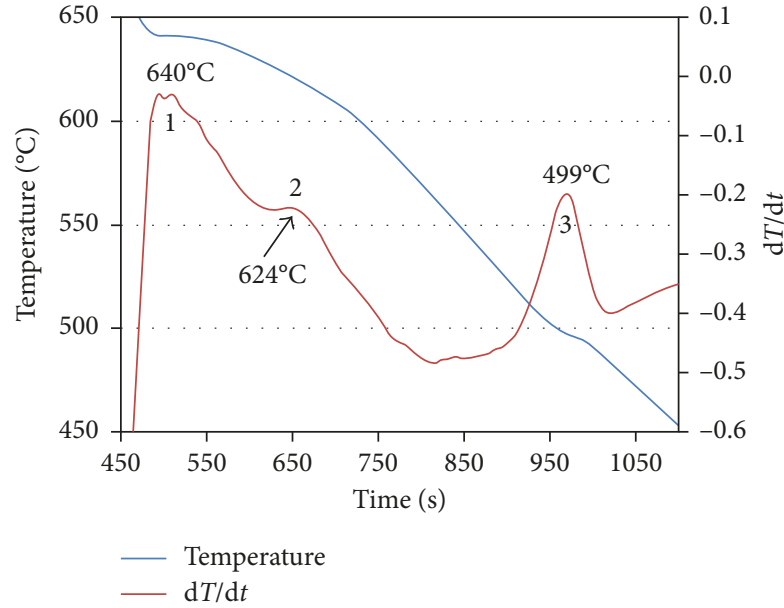

(a)

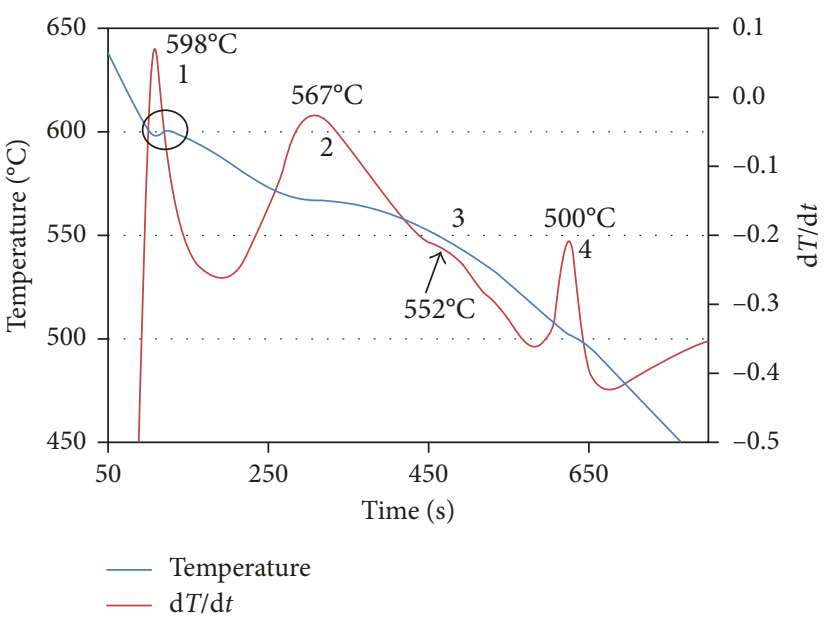

(b)

FIgURE 2: Temperature-time curves and their first derivatives obtained from (a) B0-base alloy showing 1: precipitation of $\alpha$-Al; 2: precipitation of $\alpha$-Fe intermetallic phase; 3: precipitation of $\mathrm{Al}-\mathrm{Al}_{2} \mathrm{Cu}$ eutectic and (b) D0-base alloy showing 1: precipitation of $\alpha$ - $\mathrm{Al}$; 2: precipitation of $\mathrm{Al}-\mathrm{Si}$ eutectic reaction; 3: precipitation of $\pi$-Fe intermetallic phase; 4: precipitation of $\mathrm{Al}-\mathrm{Al}_{2} \mathrm{Cu}$ eutectic.

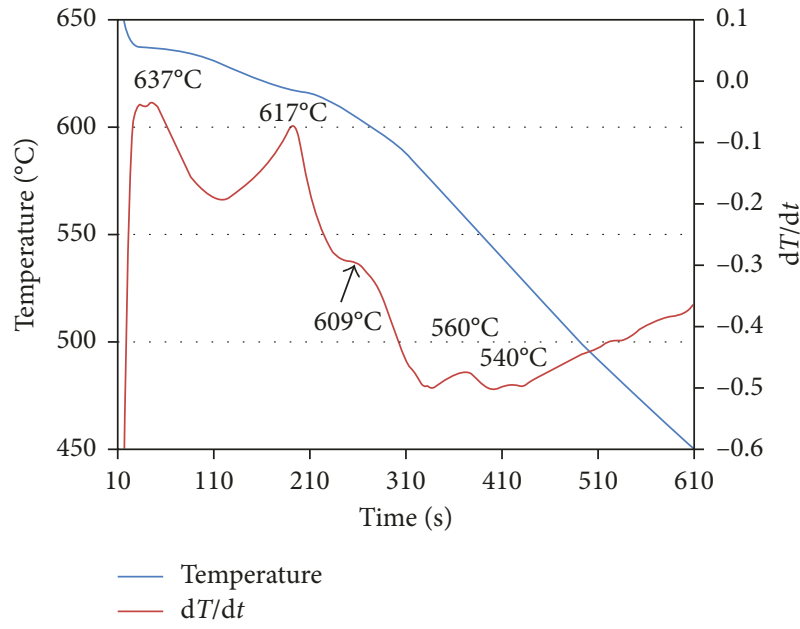

(a)

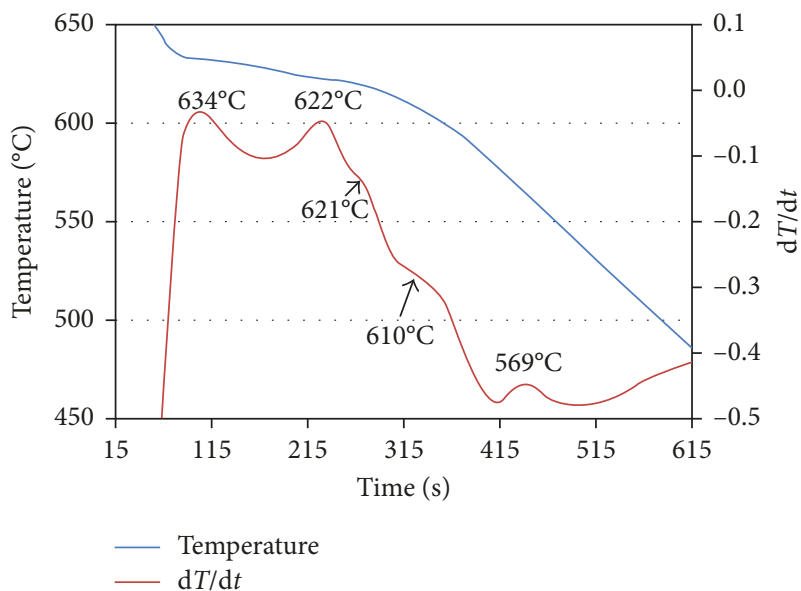

(c)

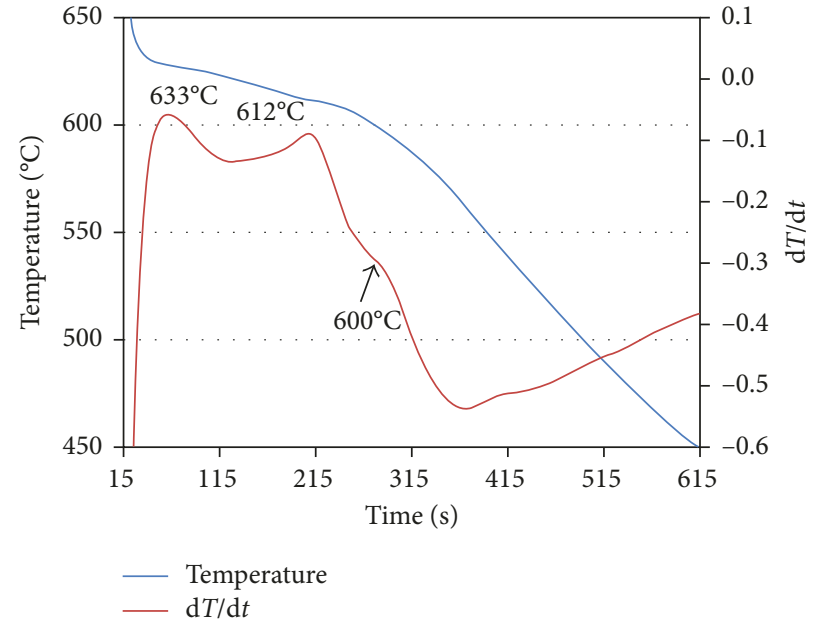

(b)

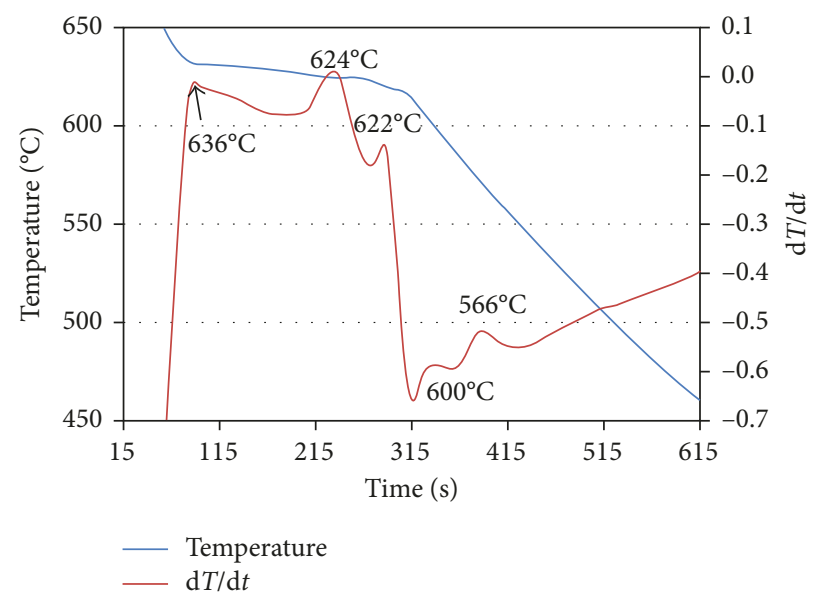

(d)

Figure 3: Temperature-time curves and their first derivatives obtained from the B0 alloy series: (a) B0 + Ce; (b) B0 + Ce + Ti; (c) B0 + La; (d) $\mathrm{B} 0+\mathrm{La}+\mathrm{Ti}$. 


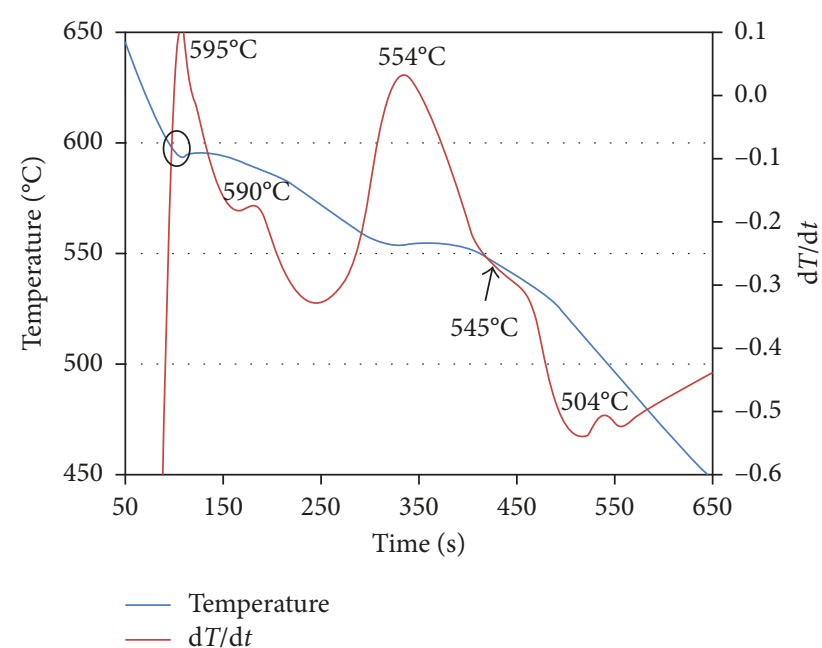

(a)

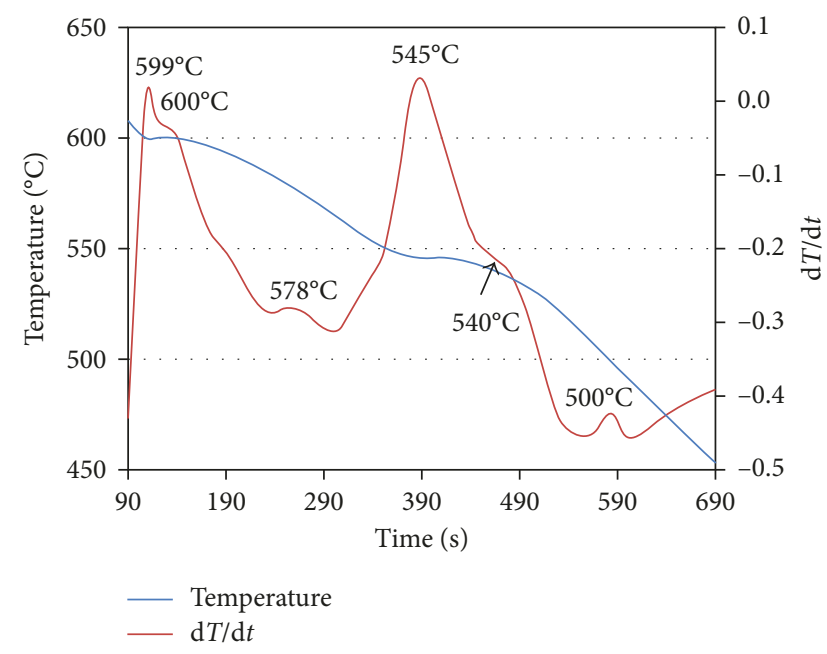

(c)

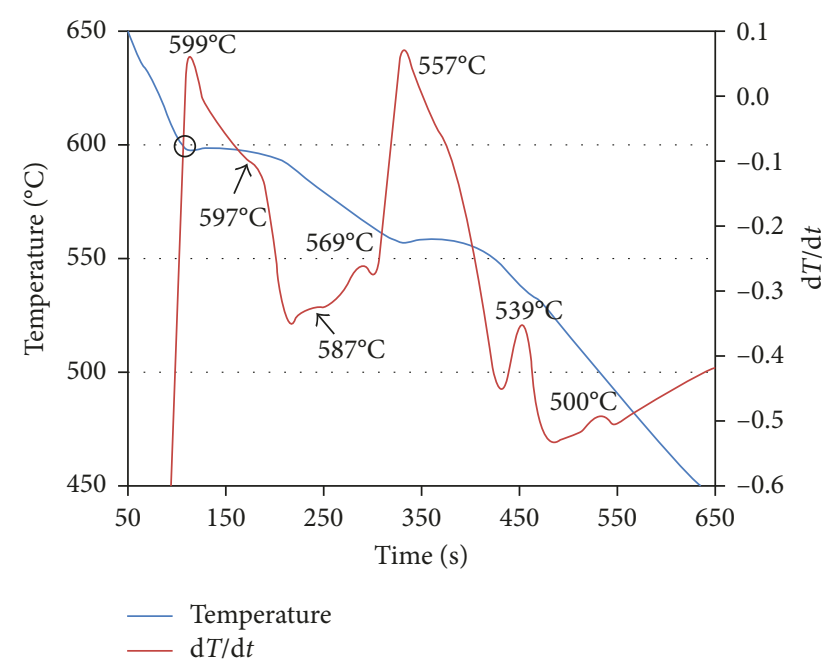

(b)

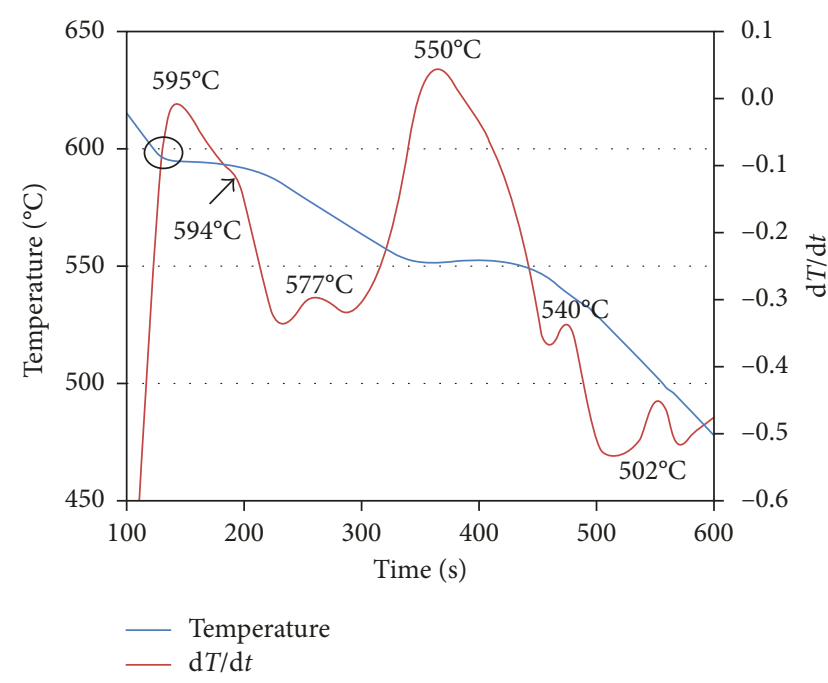

(d)

FIgURE 4: Temperature-time curves and their first derivatives obtained from the D0 alloy series: (a) D0 + Ce; (b) D0 + Ce + Ti; (c) D0 + La; (d) $\mathrm{D} 0+\mathrm{La}+\mathrm{Ti}$.

used for this research is listed in Table 1. Thermal analysis was used to obtain the solidification curves and to identify the main reactions and corresponding temperatures occurring during solidification of the different melt compositions prepared. Melting was carried out in a cylindrical graphite crucible of $2 \mathrm{~kg}$ capacity, using an electrical resistance furnace; the melting temperature was maintained at $750^{\circ} \mathrm{C}$ while alloying elements were added. Rare earth metals ( $5 \% \mathrm{La}$ or $5 \% \mathrm{Ce}$ ) were added in the form of $\mathrm{Al}-15 \mathrm{wt} . \% \mathrm{RE}$ master alloys, whereas Ti in the amount of $0.15 \%$ was added in the form of $\mathrm{Al}-5 \mathrm{wt} . \% \mathrm{Ti}-1 \mathrm{wt} . \% \mathrm{~B}$ master alloy.

A high sensitivity type-K (chromel-alumel) thermocouple, which is insulated using a double-holed ceramic tube, is attached to the centre of the graphite mold. The temperature-time data are collected using a highspeed data acquisition system linked to a computer to record the temperature-time data every 0.1 second. Figure 1 shows a schematic representation of the graphite mold (preheated at $600^{\circ} \mathrm{C}$ ), thermocouple, and thermal analysis setup. From the data obtained, the solidification curves and the corresponding first derivative curves for a number of selected alloys were plotted to identify the main reactions occurring during solidification and their corresponding temperatures. In order to support the data obtained from thermal analysis, DSC runs were carried out in the temperature range $400-700^{\circ} \mathrm{C}$ at the rate of $10^{\circ} \mathrm{C} / \mathrm{min}$.

Samples for microstructural characterization were sectioned from the central portion of the casting containing the thermocouple tip as explained elsewhere [3]. The prepared samples were examined by means of a Leica DM LM optical microscope. The grain-size measurements were carried out using a Clemex image analyzer in conjunction with the optical microscope. Phase identification was carried out using an electron probe microanalyzer (EPMA) in conjunction with energy dispersive X-ray spectroscopic (EDS) 


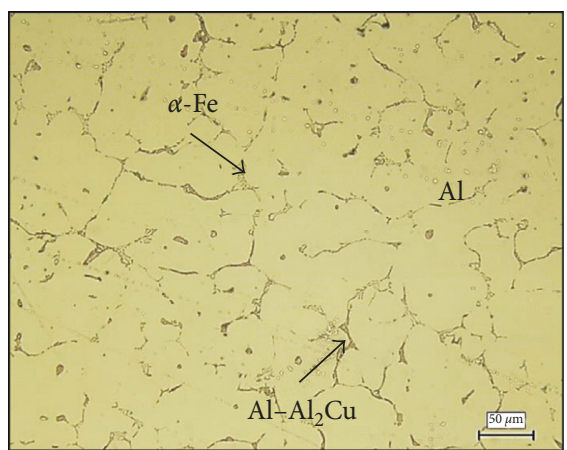

(a)

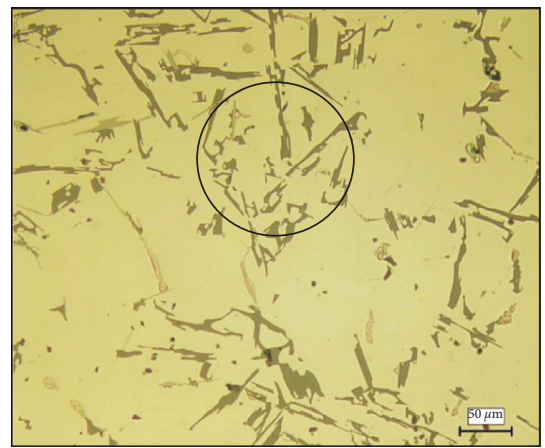

(b)

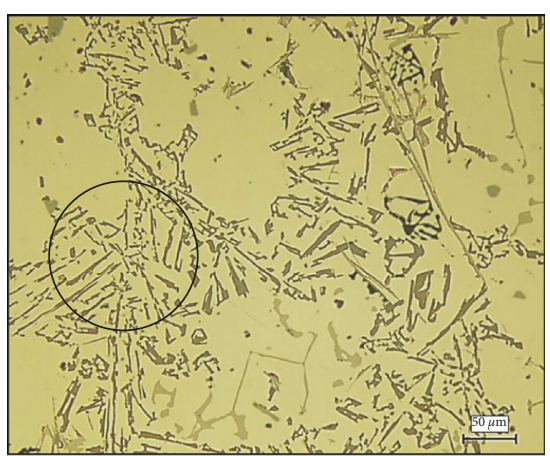

(c)

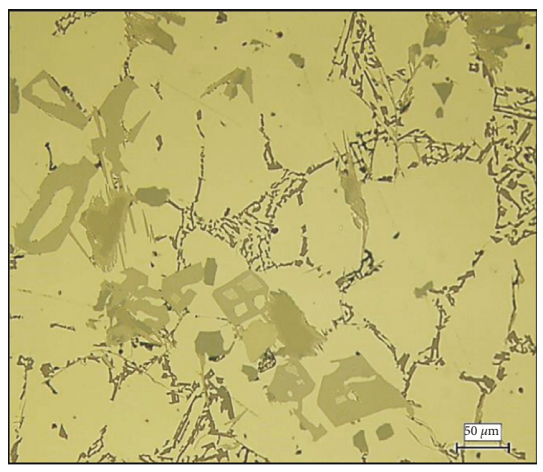

(d)

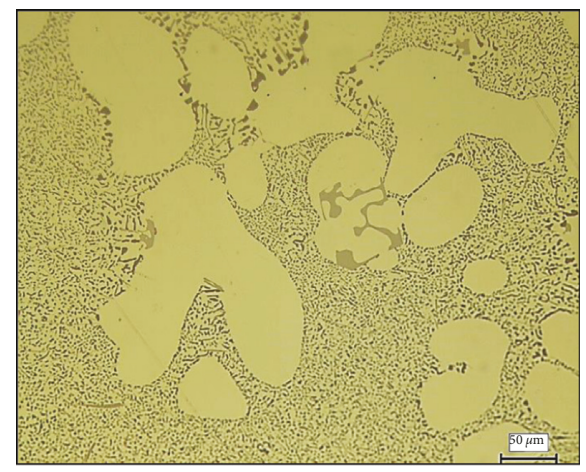

(e)

Figure 5: Optical microstructures obtained from (a) B0, (b) D0, (c) D0 + 5\%Ce + 0.15\% Ti, (d) D0 + 5\%La + 0.15\% Ti alloys, and (e) D0 alloy modified with 200 ppm Sr (no RE was added). Note marginal modification in (c) compared to (b) - see black circled areas.

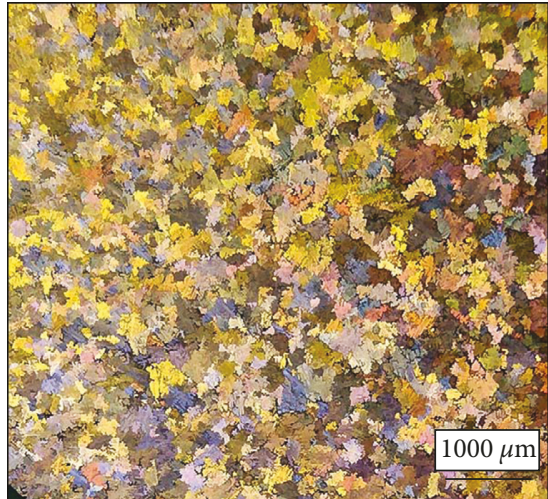

(a)

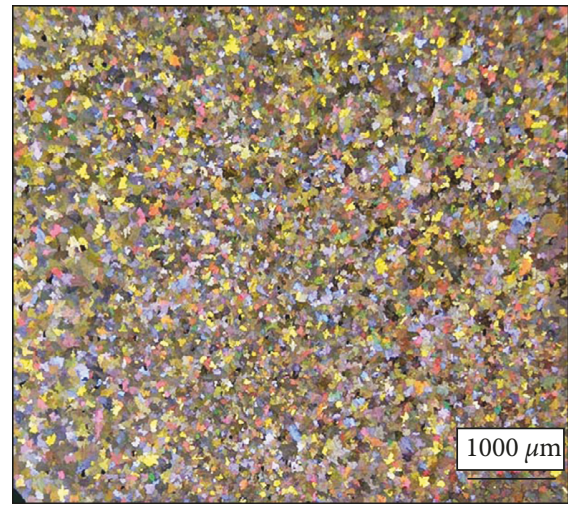

(b)

Figure 6: Macrostructures of (a) D0-based alloy and (b) D0 + 5\%Ce $+0.15 \% \mathrm{Ti}$ alloy.

and wavelength dispersive spectroscopic analysis (WDS) were required, integrating a combined JEOL JXA-89001 WD/ED microanalyzer operating at $20 \mathrm{kV}$ and $30 \mathrm{nA}$, where the size of the spot examined was $\sim 2 \mu \mathrm{m}$.

\section{Results and Discussion}

3.1. DSC Runs. The DSC heating curves of the B0-based alloys are shown in Figure 1(a). Generally, all the alloys displayed two common endothermic peaks (B and D) at temperatures ranging from 621 to $627^{\circ} \mathrm{C}$ and 635 to $637^{\circ} \mathrm{C}$, respectively. These peaks can be attributed to the melting of white intermetallic phases and $\alpha-\mathrm{Al}$, respectively. Three of the B0-based alloys displayed a small endothermic peak (A) at temperature $576-580^{\circ} \mathrm{C}$ which may also be related to the melting of white phases. The two Ce-containing B0 alloys exhibited an additional endothermic peak (C) at $625^{\circ} \mathrm{C}$ in the low-Ti alloy and at $630^{\circ} \mathrm{C}$ in the high-Ti alloy. This peak corresponds to the melting of the graycolored Al-Ti-Ce phase. The height of this peak in the latter alloy is noticeably higher than that in the former alloy, which reveals that increasing the level of Ti significantly 


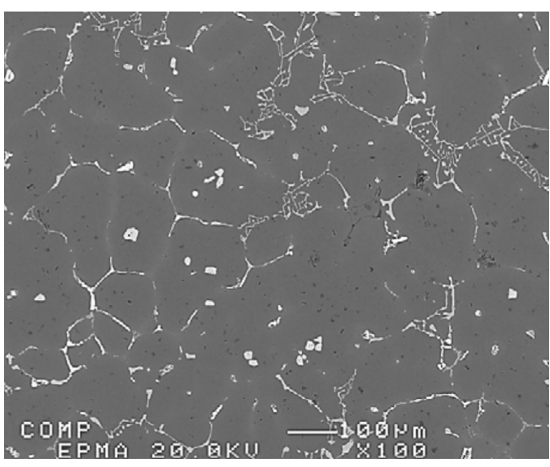

(a)

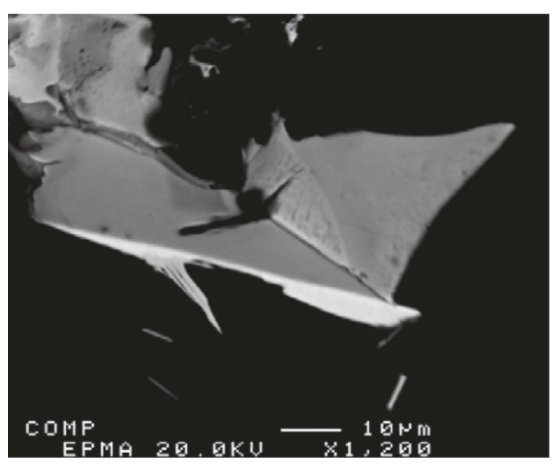

(c)

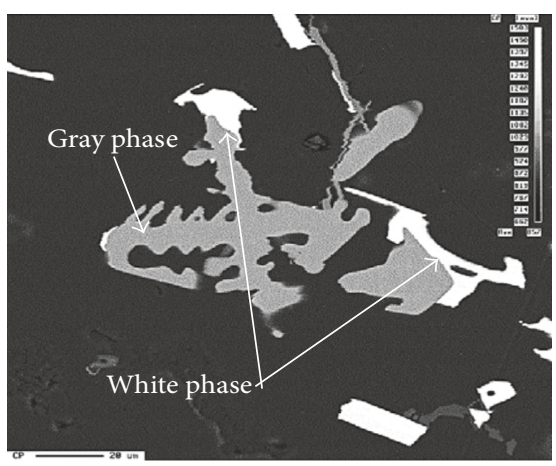

(e)

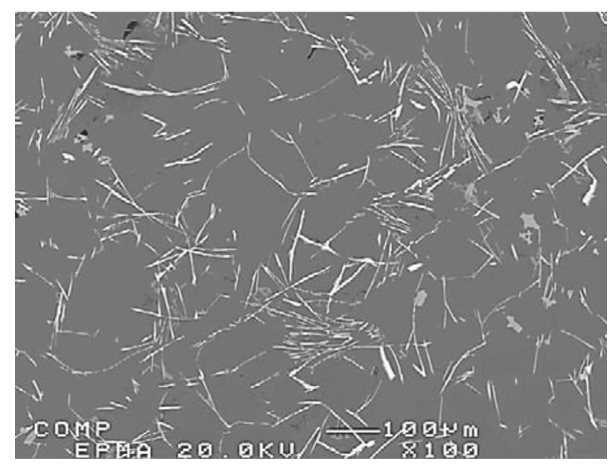

(b)

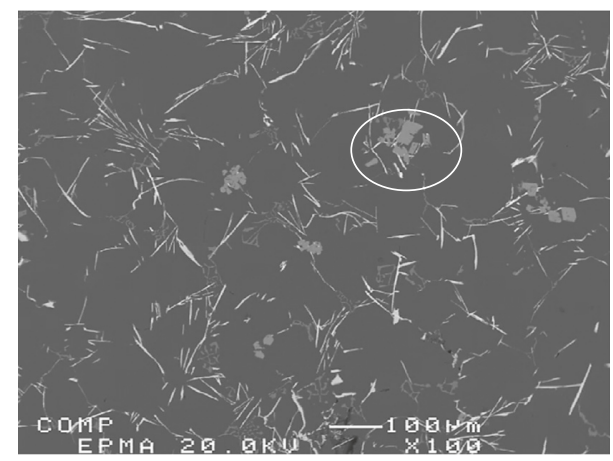

(d)

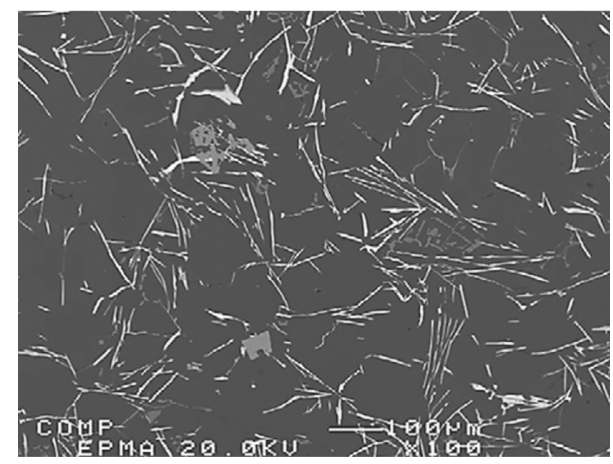

(f)

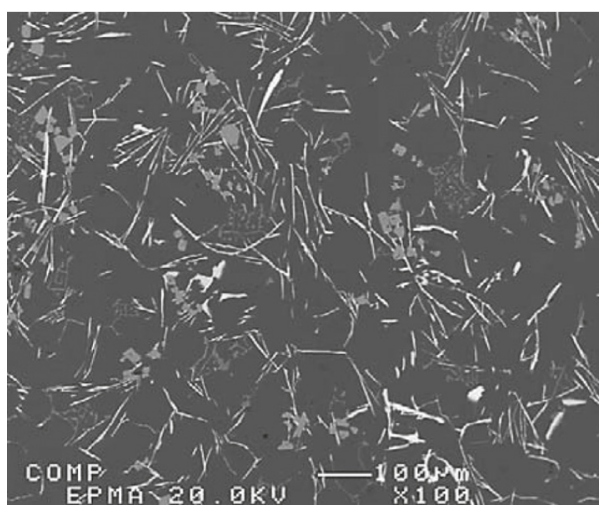

(g)

Figure 7: Backscattered electron images of (a) B0-based alloy; (b) B0 +5\%La; (c) La-rich platet in (b); (d) B0 + 5\%La + 0.2\%Ti; (e) high magnification micrograph of the gray phase circled in (d); (f) $\mathrm{B} 0+5 \% \mathrm{Ce}$; (g) $\mathrm{B} 0+5 \% \mathrm{Ce}+0.2 \% \mathrm{Ti}$ alloys. 

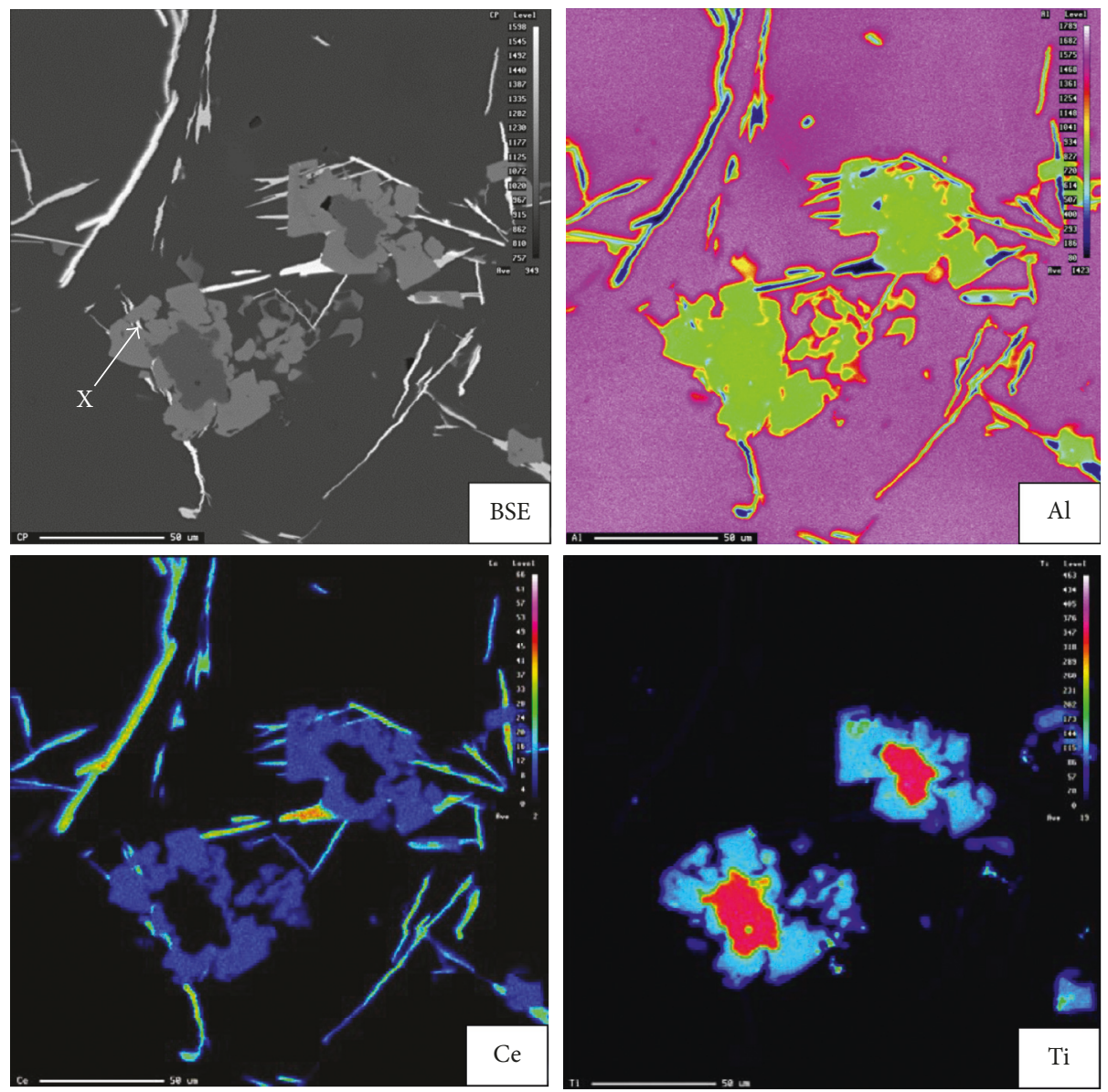

(a)

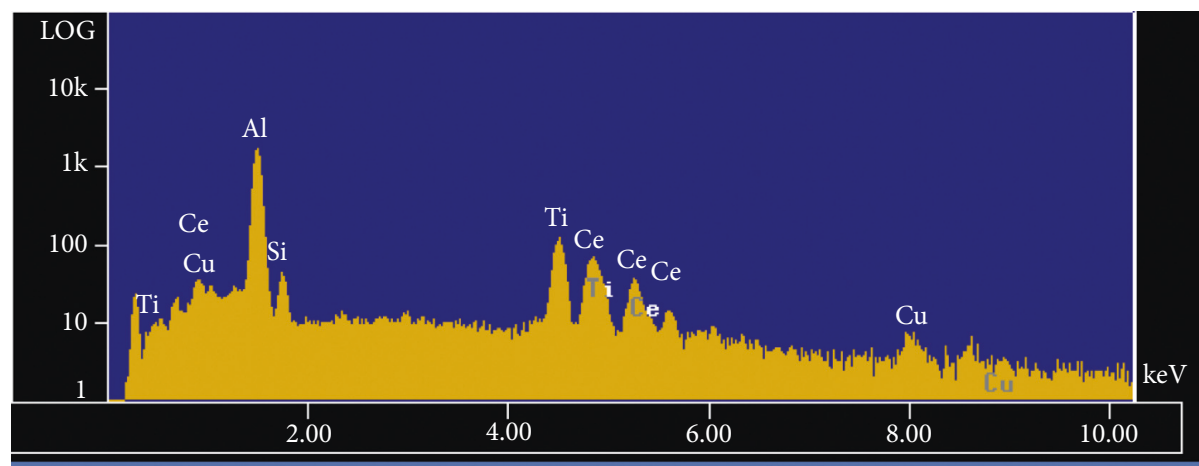

(b)

FIgURE 8: (a) Backscattered electron image and distribution of $\mathrm{Al}, \mathrm{Ce}$, and $\mathrm{Ti}$ in $\mathrm{D} 0+\mathrm{Ce}+\mathrm{Ti}$ alloy and (b) EDS spectrum corresponding to the gray phase marked $\mathrm{X}$ in (a). (Note the weak peak of Si compared to the Ti peak.)

increased the fraction of the gray-colored $\mathrm{Al}-\mathrm{Ti}-\mathrm{Ce}$ phase. The endothermic peak $\mathrm{C}$ did not appear on the DSC curves of the two La-containing B0 alloys, but the endothermic peak $\mathrm{D}$ became wider in the high-Ti alloy compared to the lowTi alloy. It could therefore be suggested that for the Lacontaining B0 alloys the melting of the gray-colored $\mathrm{Al}-\mathrm{Ti}-\mathrm{La}$ phase occurred in the same melting reaction of $\alpha$-Al.

Figure 1(b) shows the DSC cooling curves of the B0based alloys. Two common exothermic peaks appeared on these curves, namely, peaks $\mathrm{E}$ and $\mathrm{G}$, at temperatures ranging from 625 to $632^{\circ} \mathrm{C}$ and 610 to $612^{\circ} \mathrm{C}$, respectively. These peaks correspond to the solidification reactions of the $\alpha$-Al and the white-colored intermetallic phases, respectively. The intermediate exothermic peak $(\mathrm{F})$ at $615^{\circ} \mathrm{C}$ is due to the formation of the gray-colored $\mathrm{Al}-\mathrm{Ti}-\mathrm{Ce} / \mathrm{La}$ phase. The disappearance of this peak from the DSC curve of the low-Ti, Ce-containing alloy may suggest that a small amount of the gray $\mathrm{Al}-\mathrm{Ti}-\mathrm{Ce}$ phase was solidified in the same solidification reaction of the white $\mathrm{Al}-\mathrm{Si}-\mathrm{Cu}-\mathrm{Ce}$ phase which 

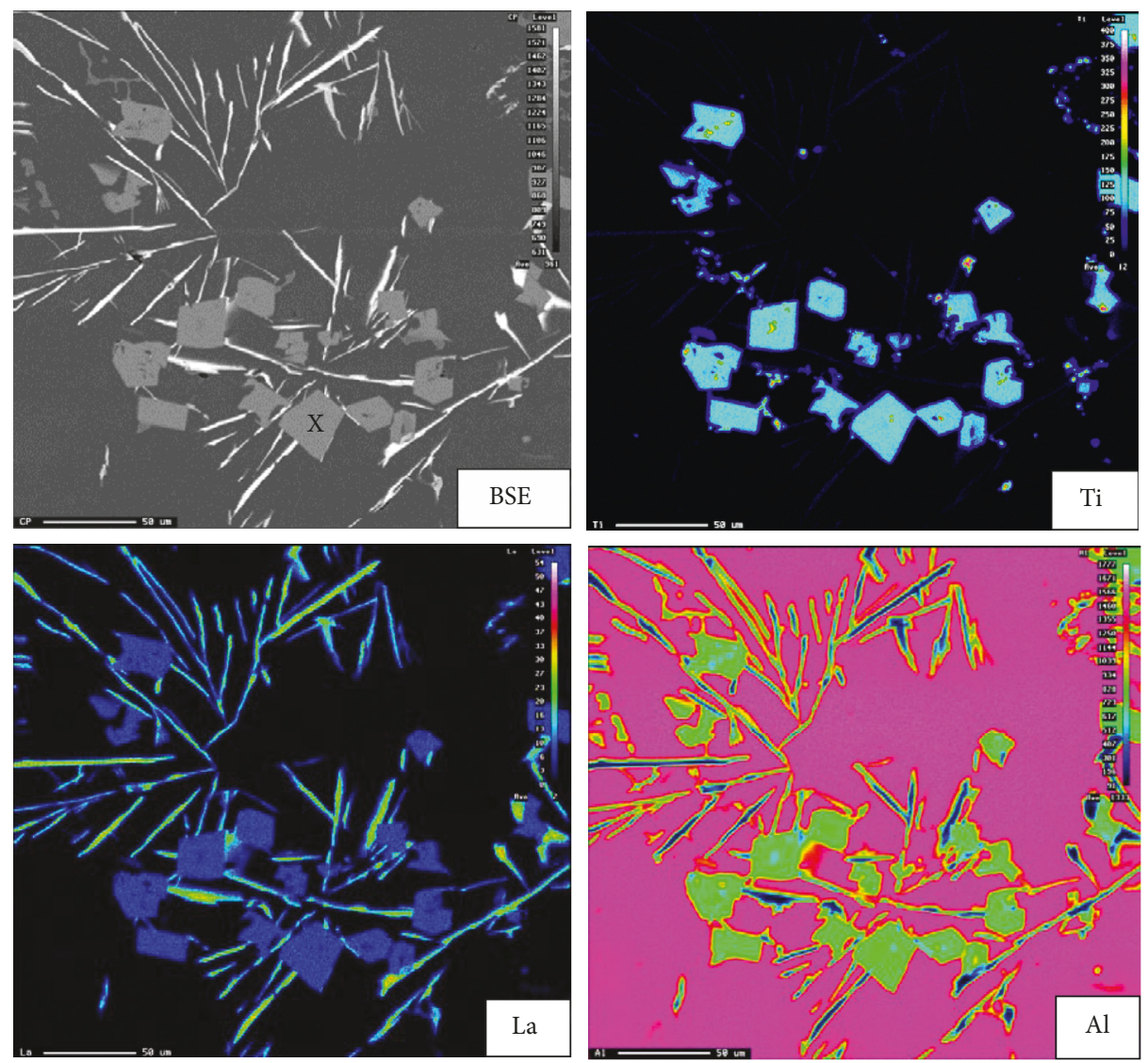

(a)

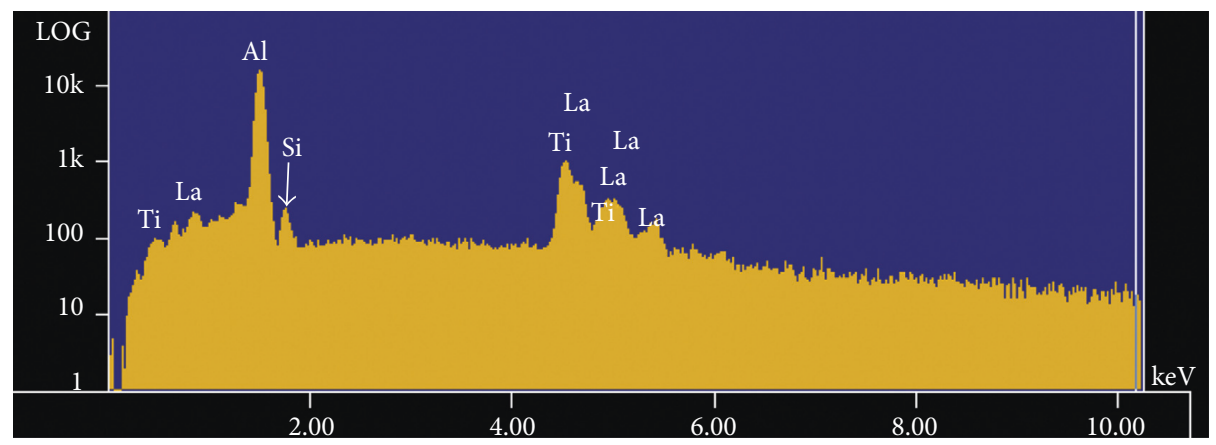

(b)

Figure 9: (a) Backscattered electron image and distribution of $\mathrm{Ti}, \mathrm{La}$, and $\mathrm{Al}$ in $\mathrm{D} 0+\mathrm{La}+\mathrm{Ti}$ alloy and (b) EDS spectrum corresponding to the gray phase marked $\mathrm{X}$ in (a).

is represented by peak G. Evidently, the addition of $\mathrm{Ti}$ promotes the formation of the gray-colored $\mathrm{Al}-\mathrm{Ti}-\mathrm{Ce} / \mathrm{La}$ phase and consequently increases the intensity of peak $\mathrm{F}$ as can be observed by comparing the DSC curves of the lowand high-Ti alloys.

The DSC heating curves of the D0-based alloys are shown in Figure 1(c). The endothermic peaks $\mathrm{H}, \mathrm{K}$, and $\mathrm{L}$ represent the melting of the $\mathrm{Al}_{2} \mathrm{Cu}$ phase, eutectic $\mathrm{Si}$, and $\alpha$ - $\mathrm{Al}$, respectively. The temperatures of these peaks varied with the alloy composition to range from 505 to $507^{\circ} \mathrm{C}, 569$ to $573^{\circ} \mathrm{C}$, and 586 to $600^{\circ} \mathrm{C}$, respectively. The endothermic peaks I and J which occurred at $540^{\circ} \mathrm{C}$ and $552^{\circ} \mathrm{C}$, respectively, could be attributed to the melting of the white-colored Ce-/La-rich intermetallic phases. Taking into consideration the increase in its size with increasing the $\mathrm{Ti}$ level whether for Ce- or Lacontaining alloys, the last endothermic peak (M) which occurred at $599-607^{\circ} \mathrm{C}$ could be related to the melting of the gray $\mathrm{Al}-\mathrm{Ti}-\mathrm{Ce} / \mathrm{La}$ phase. Figure $1(\mathrm{~d})$ shows the DSC cooling curves of the D0-based alloys. The two major exothermic peaks $(\mathrm{N}$ and Q) correspond to the solidification reaction of $\alpha-\mathrm{Al}$ and the eutectic $\mathrm{Si}$, respectively. The other exothermic peaks, namely $\mathrm{O}, \mathrm{P}$, and $\mathrm{R}$, could be due to the solidification of whitecolored Ce-/La-rich intermetallic phases. No distinct exothermic peak was displayed by the DSC curve for the formation of the gray Al-Ti-Ce/La phase, which implies that this phase may be cosolidified with $\alpha$-Al. 

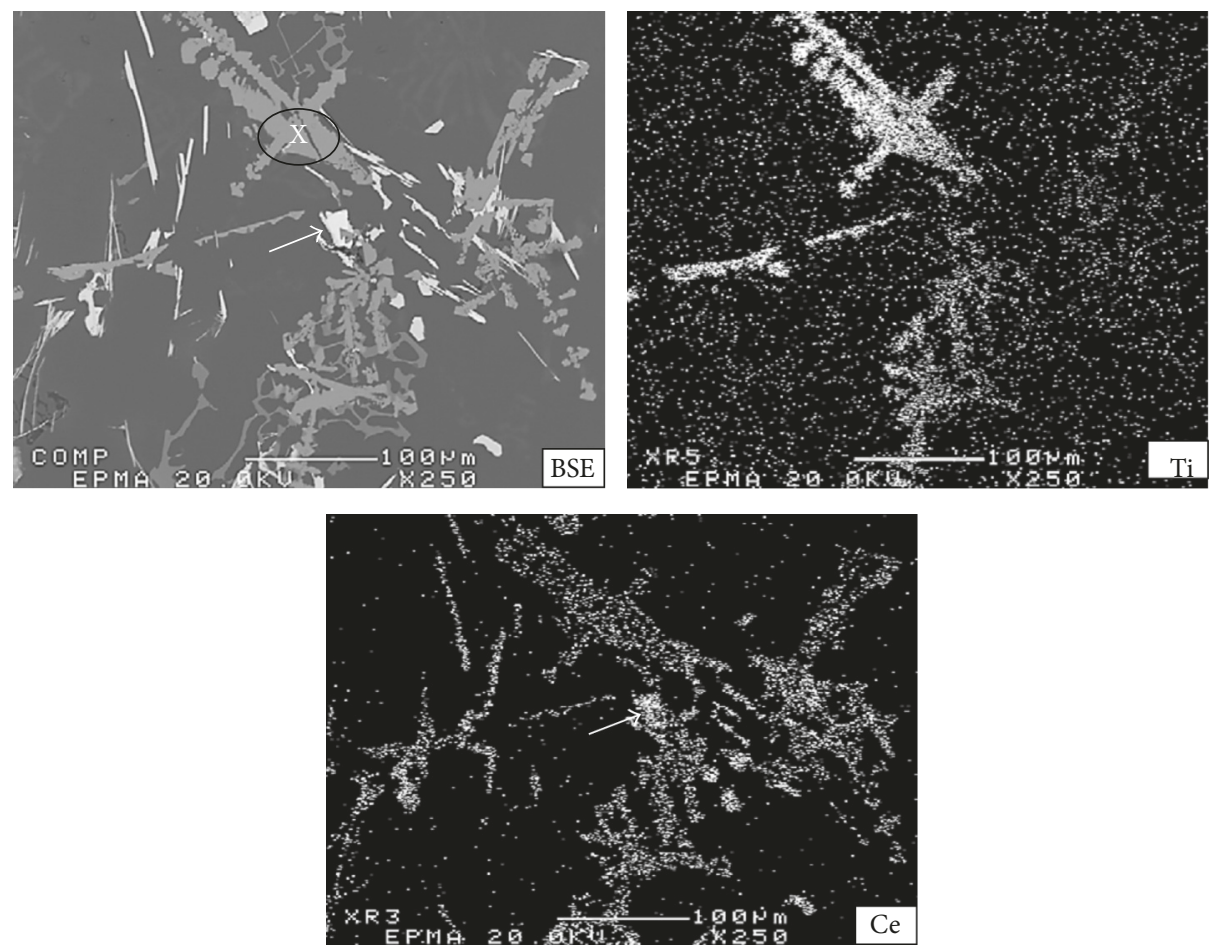

(a)

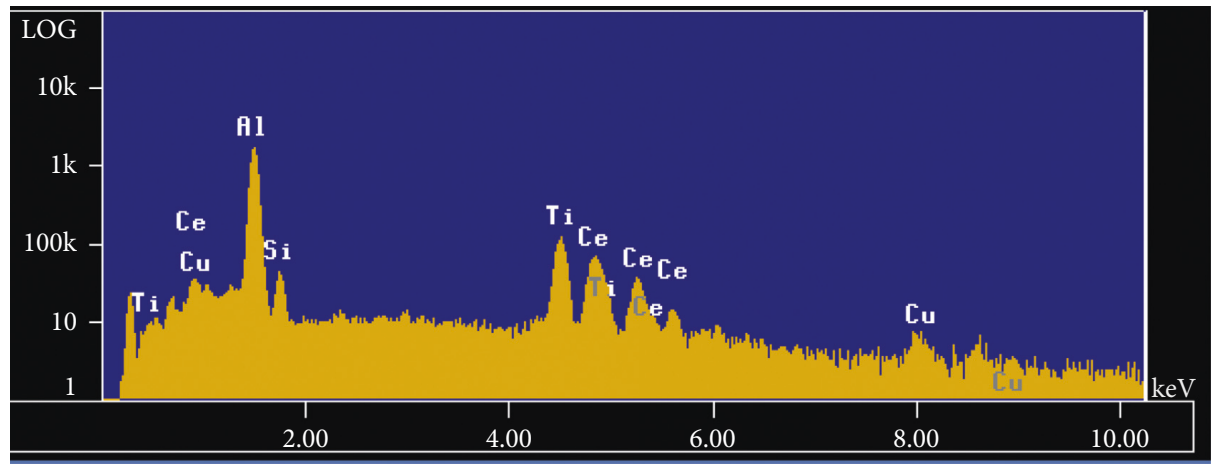

(b)

FIGURE 10: (a) Backscattered electron image and distribution of Ti and $\mathrm{Ce}$ in $\mathrm{D} 0+\mathrm{Ce}+\mathrm{Ti}$ alloy and (b) EDS spectrum corresponding to the gray phase marked $\mathrm{X}$ in (a). White arrows indicate high Ce concentration in the white-phase particles.

3.2. Thermal Analysis. Figure 2(a) presents the solidification curve and its first derivative obtained from the B0-based alloy. According to Elgallad et al. [15], the observed peaks correspond to the successive precipitation of $\alpha$-Al, $\alpha$-Fe intermetallic, and $\left(\mathrm{Al}-\mathrm{Al}_{2} \mathrm{Cu}\right)$ eutectic phases. Addition of $\mathrm{Si}$ to $\mathrm{B} 0$ alloy, giving $\mathrm{D} 0$ alloy, resulted in the reduction of the alloy melting temperature from $641^{\circ} \mathrm{C}$ to $598^{\circ} \mathrm{C}$ coupled with the appearance of the $\mathrm{Al}-\mathrm{Si}$ eutectic plateau at $567^{\circ} \mathrm{C}[3]$, as shown in Figure 2(b). The circled area in Figure 2(b) reveals the presence of undercooling since the $\mathrm{Ti}$ concentration is below $0.05 \%$.

Eutectic modification of $\mathrm{Al}-\mathrm{Si}$ alloys with rare earth metals was studied by Nogita et al. [16]. The authors suggested that all of the rare earth elements caused a depression of the eutectic growth temperature. At best, the RE elements resulted in only a small degree of refinement of the plate-like silicon. Also, many of the rare earth additions significantly altered the eutectic solidification mode from that of the unmodified alloy.

Figures 3 and 4 demonstrate the effect of adding a relatively large amount of RE metals (without or with $0.15 \% \mathrm{Ti}$ ) to both base alloys. Based on these figures, it is clear that these additions resulted in

(1) appearance of several new peaks in the zone between $\alpha$ - $\mathrm{Al}$ and $\left(\mathrm{Al}-\mathrm{Al}_{2} \mathrm{Cu}\right)$ eutectic,

(2) depression in the (Al-Si) eutectic temperature in D0 alloys (approximately $16^{\circ} \mathrm{C}$ ),

(3) increase in the solidification zone by about $18^{\circ} \mathrm{C}$.

As reported previously by the present authors [3, 17], the observed depression in the eutectic temperature due 


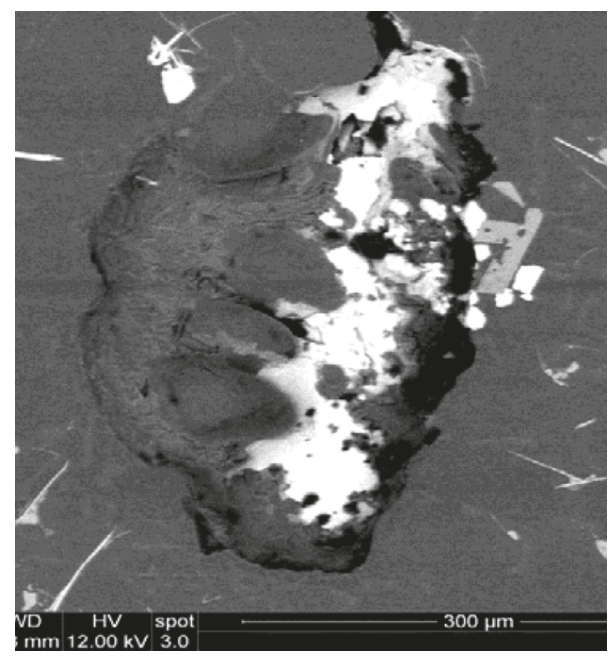

(a)
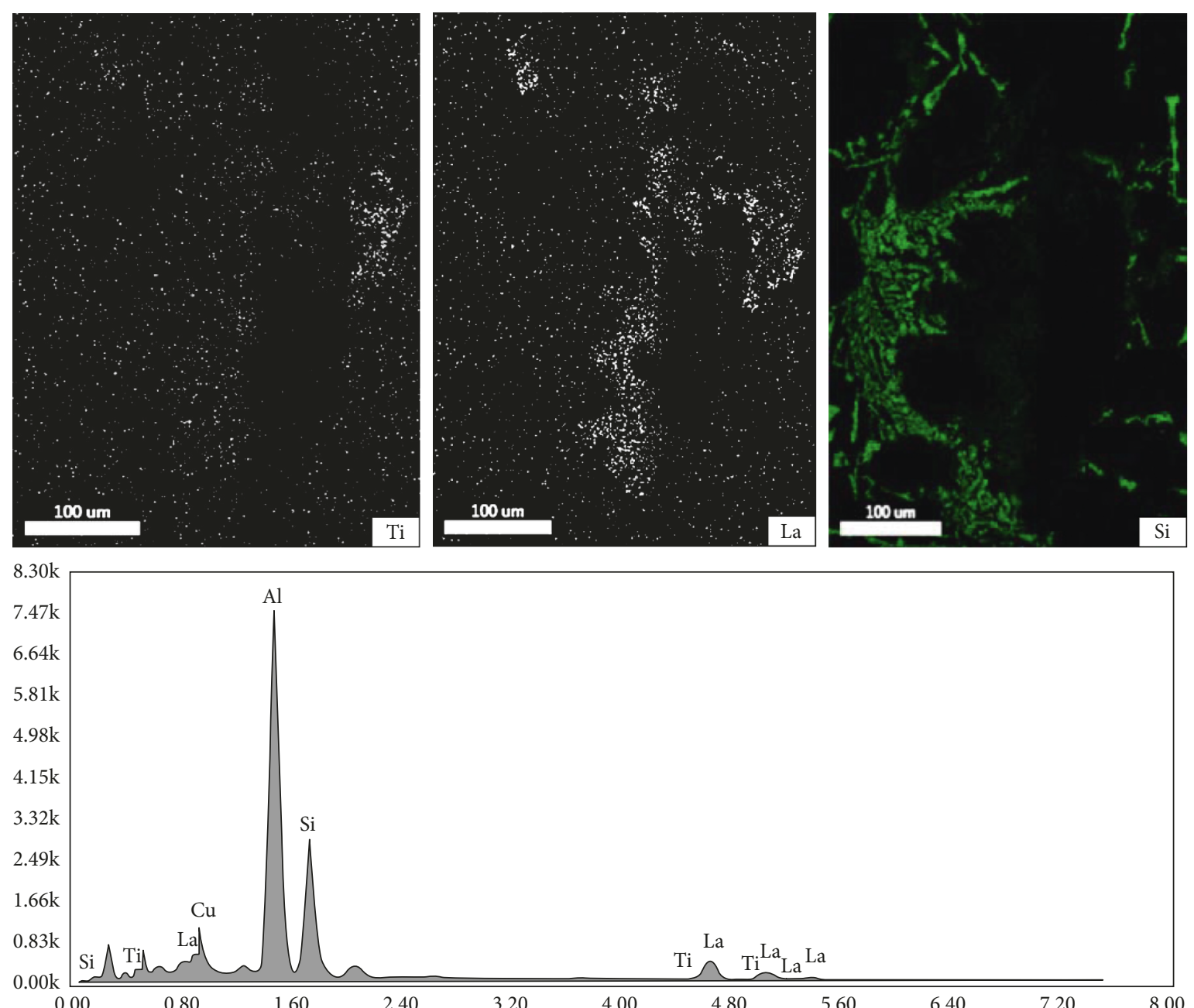

Lsec: 354.80 Cnts $0.000 \mathrm{keV}$ Det: Octane Super Det

(c)

Figure 11: (a) Backscattered electron image and (b) elemental distribution in D0 + La + Ti alloy, (c) X-ray images of Ti, La, and Si in (a), showing the presence of La in the RE-rich plate, EDS spectrum corresponding to the white phase marked X in (a). 

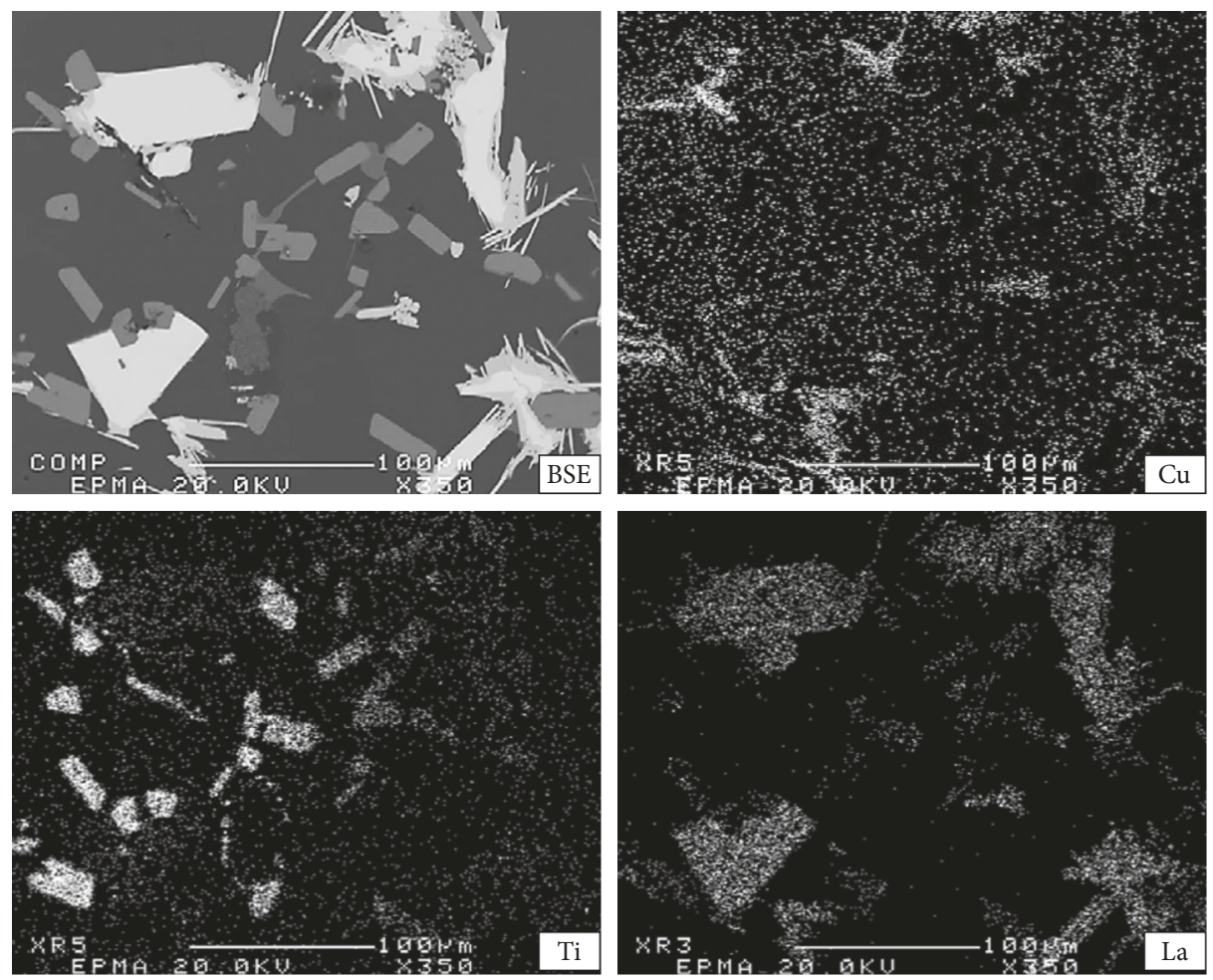

(a)

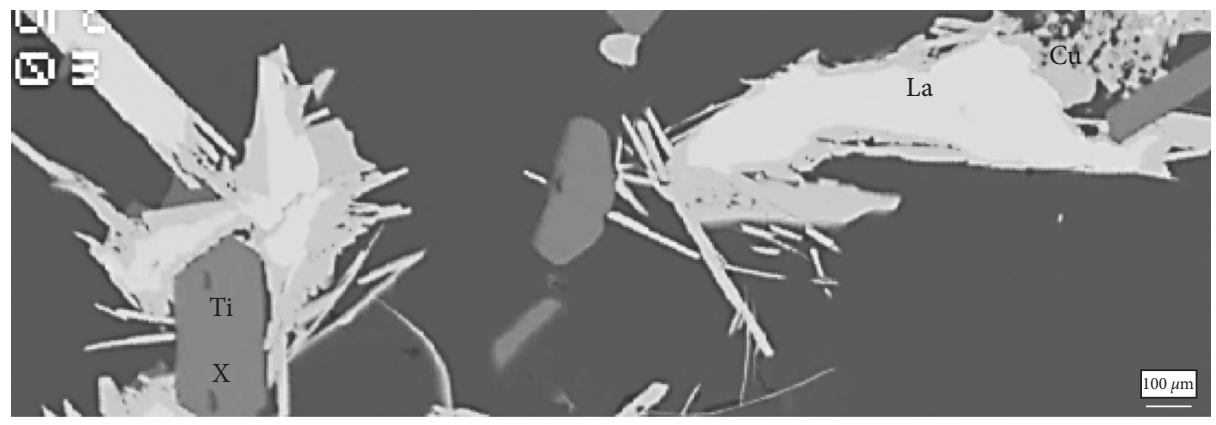

(b)

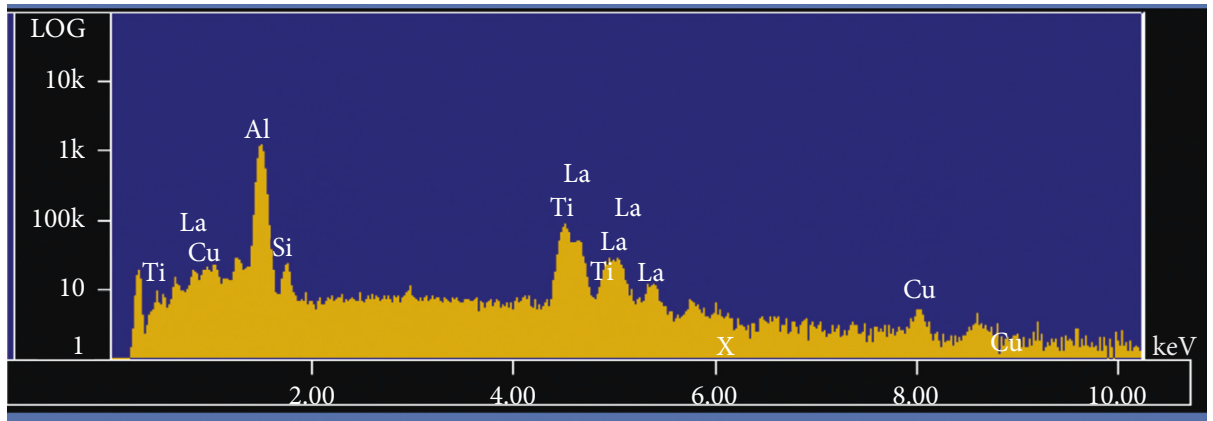

(c)

Figure 12: (a) Backscattered electron image and distribution of $\mathrm{Cu}, \mathrm{Ti}$, and $\mathrm{La}$ in $\mathrm{D} 0+\mathrm{La}+\mathrm{Ti}$ alloy, (b) enlarged micrograph of circled area in (a), and (c) EDS spectrum corresponding to the gray phase marked X in (b). (Note the weak Cu and Si peaks in the gray phase.)

to addition of $\mathrm{RE}$ metals is not necessarily related to modification of the eutectic Si particles as shown in Figure 5. It should be mentioned that only La revealed partial modification but was not as effective a modifier as $\mathrm{Sr}$ in the Sr-treated alloys. For example, the Si particle average area is initially $17.85 \mu \mathrm{m}^{2}$ compared to $15.64 \mu \mathrm{m}^{2}$ and $10.67 \mu \mathrm{m}^{2}$ with the addition of $5 \%$ of $\mathrm{Ce}$ and $\mathrm{La}$, respectively, and $3.2 \mu \mathrm{m}^{2}$ in the Sr-treated alloy.

Figure 6 exhibits the importance of adding $\mathrm{Ti}$ in refining the alloy grain size. However, due to the high affinity 

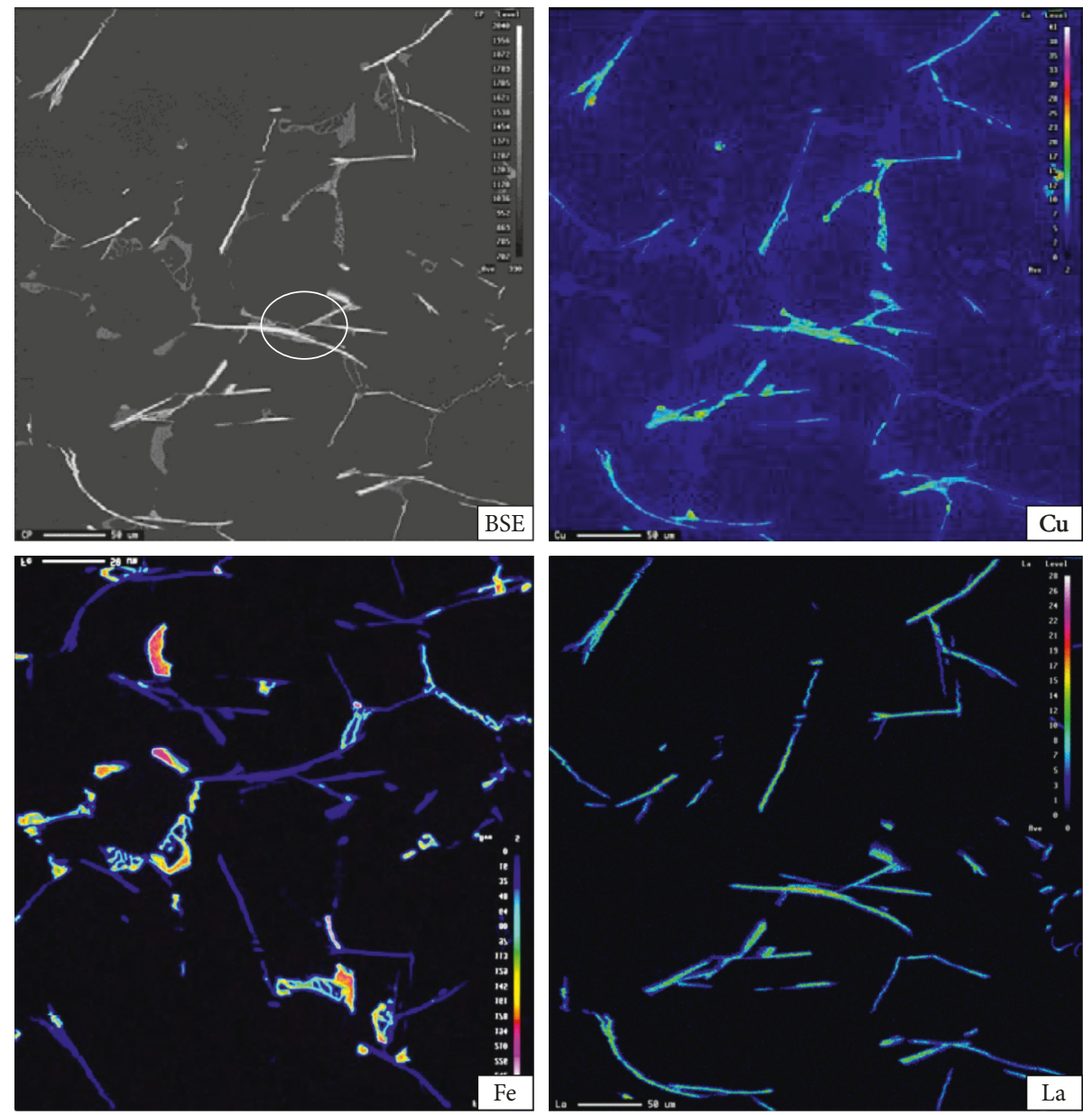

(a)

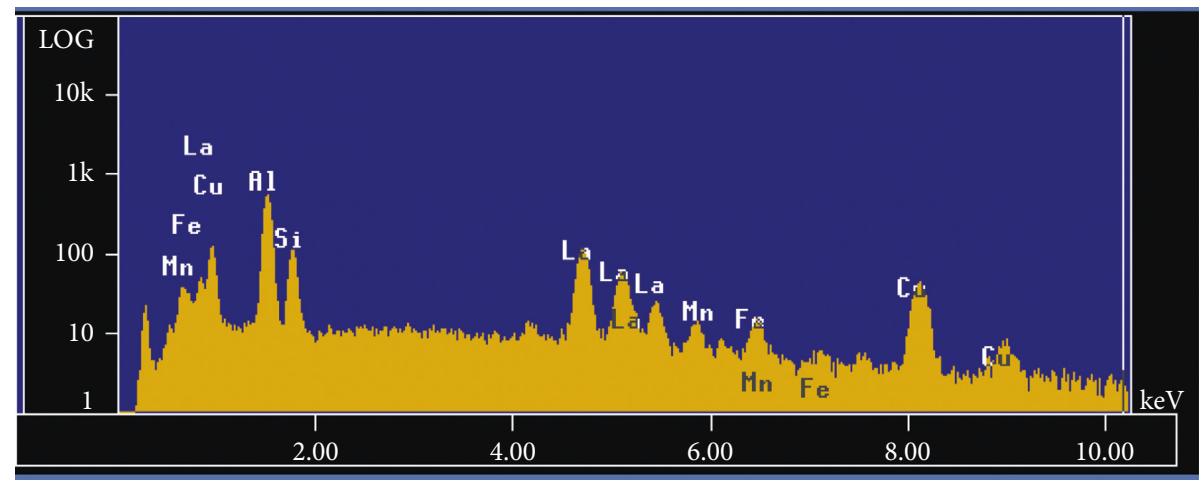

(b)

FIGURE 13: La-transition metal interactions in D0 + La alloy: (a) backscattered electron image and corresponding Cu, Fe, and La images and (b) EDS spectrum of white phase circled in (a).

of Ti to react with the RE metals, this leads to precipitation of a fairly large amount of intermetallics as displayed in Figure 5(d). The nature of these intermetallics will be discussed in the next section. The observed increase in the freezing zone in RE-treated alloys may lead to formation of shrinkage porosity. Since the molten metal was not degassed prior to casting, the volume fraction of porosity may not be reliable.

\section{Microstructural Characterization}

In this section, a series of electron micrographs will be presented to illustrate the effect of the added RE metals without $(<0.05 \%)$ and with $(0.15 \%)$ Ti on the morphology and density of the precipitated intermetallics. Figure 7 (a) exhibits the microstructure of the base B0 alloy showing the three main phases as described in the previous section. 

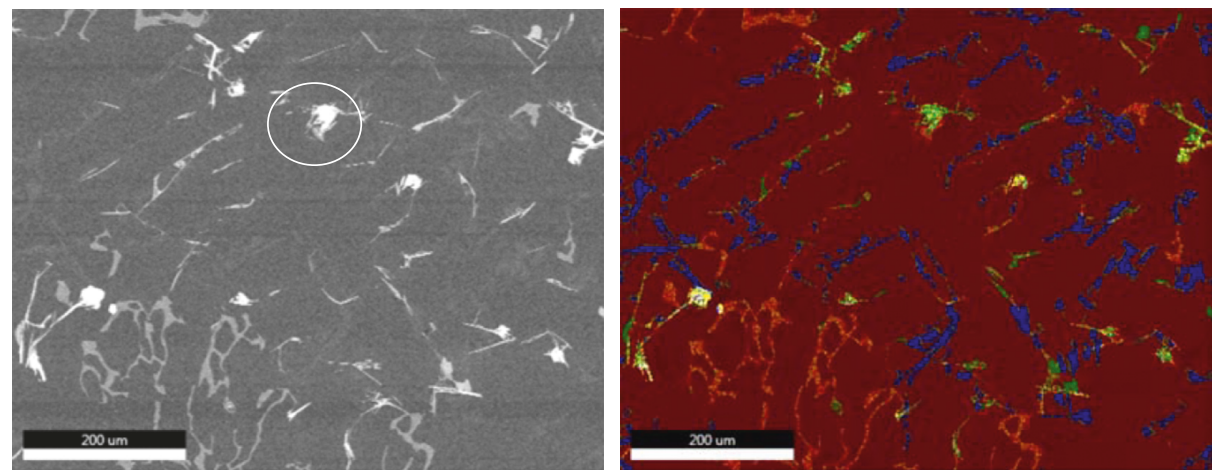

(a)
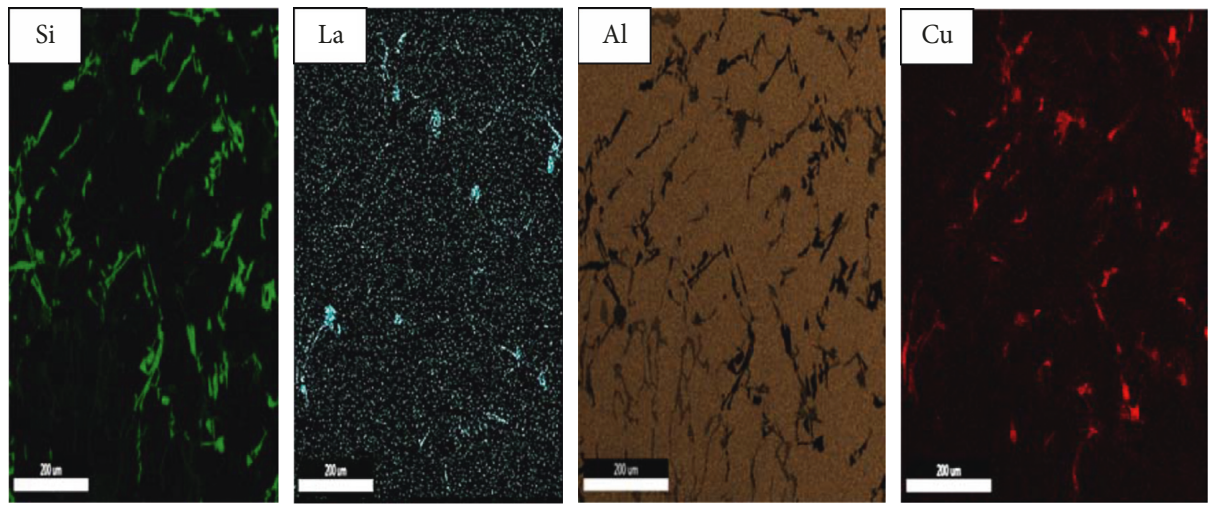

(b)

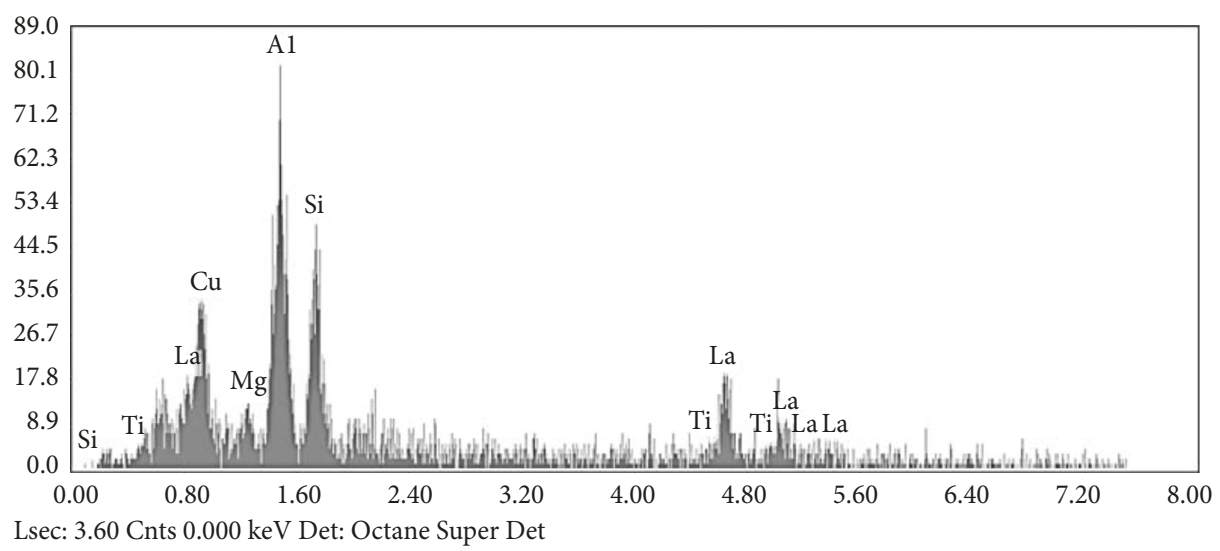

(c)

FIGURE 14: La-Cu interactions in D0 + La alloy: (a) backscattered image, (b) corresponding X-ray images of Si, La, $\mathrm{Al}$, and Cu, and (c) EDS spectrum of white phase circled in (a).

Addition of RE ( $\mathrm{La}$ or $\mathrm{Ce}$ ) resulted in the precipitation of an intensive amount of thin, long particles of a white phase. The high-magnification micrograph in Figure 7 (c) reveals the platelet-like morphology of this white phase. Addition of $\mathrm{Ti}+\mathrm{RE}$ caused the precipitation of a gray phase in the form of "sludge" as shown in Figure $7(\mathrm{e})$-note the precipitation of the white phase on the edges of the sludge.

Based on the chemical composition listed in Table 1, the Fe-based sludge should precipitate at about $650^{\circ} \mathrm{C}$, which exceeds the melting temperatures of the two alloys. Similarly, the gray-phase particles (judging by their morphology) could as well have precipitated in the liquid state prior to solidification and acted as nucleation sites for the white phase.

From the present results, both La- and Ce-rich precipitates are found to have more or less the same shape, as illustrated in Figures $7(\mathrm{f})$ and $7(\mathrm{~g})$. In order to distinguish between the different types of particles, WDS and EDS techniques were employed. It should be mentioned as well that similar observations were made when D0 alloy was used; that is, the amount of Si seems to have no bearing on the precipitated phases. Figure 8 reveals the possibility of the precipitation of RE-based intermetallics on the existing Ti-rich particles (possibly $\mathrm{Al}_{3}$ Ti particles). Figures 9 and 10 
TABLE 2: WDS analysis of the RE-based phases observed in the alloys studied.

\begin{tabular}{|c|c|c|c|c|c|c|c|c|c|c|c|}
\hline \multirow{2}{*}{ Alloy code } & \multirow{2}{*}{ Phase/color } & \multicolumn{9}{|c|}{ Element (at.\%) } & \multirow{2}{*}{ Suggested formula } \\
\hline & & $\mathrm{Al}$ & $\mathrm{Ti}$ & $\mathrm{Fe}$ & $\mathrm{Cu}$ & $\mathrm{Mg}$ & $\mathrm{Cr}$ & $\mathrm{Si}$ & $\mathrm{Ce}$ & $\mathrm{La}$ & \\
\hline \multirow{12}{*}{$\begin{array}{l}\text { D0 + } 5 \text { wt. } \% \\
\text { La } \\
\text { (with Ti) }\end{array}$} & 1 white & 33.13 & 0.000 & 0.021 & 0.269 & 0.000 & 0.121 & 30.26 & 1.819 & 34.31 & AlLaSi \\
\hline & 2 white & 34.56 & 0.000 & 0.000 & 0.426 & 0.000 & 0.118 & 27.51 & 1.955 & 35.37 & AlLaSi \\
\hline & 3 white & 35.03 & 0.000 & 0.000 & 0.343 & 0.000 & 0.102 & 27.63 & 1.833 & 35.01 & AlLaSi \\
\hline & 4 white & 36.57 & 0.000 & 0.000 & 0.290 & 0.000 & 0.132 & 25.93 & 1.807 & 35.23 & AlLaSi \\
\hline & 5 white & 34.72 & 0.000 & 0.006 & 0.344 & 0.000 & 0.076 & 27.82 & 1.775 & 35.20 & AlLaSi \\
\hline & 6 white & 50.11 & 0.000 & 0.000 & 0.083 & 0.938 & 0.028 & 26.49 & 1.379 & 20.95 & $\mathrm{Al}_{2} \mathrm{LaSi}$ \\
\hline & 7 white & 45.61 & 0.000 & 0.017 & 8.933 & 0.674 & 0.077 & 22.79 & 1.133 & 20.53 & $\mathrm{Al}_{9} \mathrm{La}_{4} \mathrm{Cu}_{2} \mathrm{Si}_{4}$ \\
\hline & 1 grey & 85.74 & 6.676 & 0.013 & 0.469 & 1.541 & 0.183 & 0.801 & 0.581 & 3.815 & $\mathrm{Al}_{21} \mathrm{Ti}_{2} \mathrm{La}$ \\
\hline & 2 grey & 85.39 & 6.543 & 0.035 & 0.606 & 1.570 & 0.279 & 0.919 & 0.626 & 3.767 & $\mathrm{Al}_{21} \mathrm{Ti}_{2} \mathrm{La}$ \\
\hline & 3 grey & 85.48 & 6.343 & 0.046 & 0.707 & 1.307 & 0.346 & 0.888 & 0.567 & 3.764 & $\mathrm{Al}_{21} \mathrm{Ti}_{2} \mathrm{La}$ \\
\hline & 4 grey & 85.20 & 6.439 & 0.013 & 0.588 & 1.737 & 0.289 & 1.033 & 0.597 & 3.832 & $\mathrm{Al}_{21} \mathrm{Ti}_{2} \mathrm{La}$ \\
\hline & 5 grey & 85.33 & 6.588 & 0.008 & 0.691 & 1.264 & 0.238 & 1.262 & 0.525 & 3.846 & $\mathrm{Al}_{21} \mathrm{Ti}_{2} \mathrm{La}$ \\
\hline \multirow{10}{*}{$\begin{array}{l}\text { D0 + } 5 \text { wt. } \% \\
\text { La } \\
\text { (without Ti) }\end{array}$} & 1 white & 33.07 & 0.000 & 0.000 & 0.272 & 0.000 & 0.136 & 29.68 & 0.358 & 36.44 & AlLaSi \\
\hline & 2 white & 31.65 & 0.000 & 0.000 & 0.512 & 0.000 & 0.144 & 30.71 & 0.406 & 36.54 & AlLaSi \\
\hline & 3 white & 31.57 & 0.000 & 0.031 & 0.463 & 0.033 & 0.093 & 30.20 & 0.341 & 37.18 & AlLaSi \\
\hline & 4 white & 31.46 & 0.000 & 0.000 & 0.513 & 0.000 & 0.133 & 30.07 & 0.413 & 37.32 & AlLaSi \\
\hline & 5 white & 32.24 & 0.000 & 0.000 & 0.397 & 0.000 & 0.131 & 29.72 & 0.380 & 37.09 & AlLaSi \\
\hline & 1 grey & 84.70 & 7.469 & 0.006 & 0.417 & 1.098 & 0.112 & 1.667 & 0.102 & 4.253 & $\mathrm{Al}_{21} \mathrm{Ti}_{2} \mathrm{La}$ \\
\hline & 2 grey & 84.62 & 7.388 & 0.001 & 0.546 & 1.063 & 0.134 & 1.645 & 0.109 & 4.286 & $\mathrm{Al}_{21} \mathrm{Ti}_{2} \mathrm{La}$ (with traces of $\mathrm{Si}$ and $\mathrm{Cu}$ ) \\
\hline & 3 grey & 84.47 & 7.417 & 0.022 & 0.684 & 1.092 & 0.112 & 1.546 & 0.086 & 4.340 & $\mathrm{Al}_{21} \mathrm{Ti}_{2} \mathrm{La}$ \\
\hline & 4 grey & 84.45 & 7.357 & 0.011 & 0.995 & 0.959 & 0.120 & 1.480 & 0.092 & 4.281 & $\mathrm{Al}_{21} \mathrm{Ti}_{2} \mathrm{La}$ \\
\hline & 5 grey & 84.69 & 7.528 & 0.000 & 0.561 & 1.412 & 0.118 & 1.162 & 0.097 & 4.264 & $\mathrm{Al}_{21} \mathrm{Ti}_{2} \mathrm{La}$ \\
\hline \multirow{10}{*}{$\begin{array}{l}\text { D0 + } 5 \text { wt. } \% \\
\text { Ce } \\
\text { (with Ti) }\end{array}$} & 1 white & 51.26 & 0.000 & 0.000 & 0.073 & 0.416 & 0.001 & 25.64 & 21.82 & 0.710 & $\mathrm{Al}_{2} \mathrm{CeSi}$ \\
\hline & 2 white & 45.37 & 0.000 & 0.000 & 0.276 & 0.391 & 0.011 & 28.55 & 24.59 & 0.803 & $\mathrm{Al}_{2} \mathrm{CeSi}$ \\
\hline & 3 white & 45.49 & 0.000 & 0.017 & 0.292 & 0.358 & 0.022 & 28.42 & 24.56 & 0.838 & $\mathrm{Al}_{2} \mathrm{CeSi}$ \\
\hline & 4 white & 45.15 & 0.000 & 0.014 & 0.259 & 0.331 & 0.000 & 29.20 & 24.20 & 0.810 & $\mathrm{Al}_{2} \mathrm{CeSi}$ \\
\hline & 5 white & 51.86 & 0.000 & 0.009 & 0.077 & 0.480 & 0.023 & 25.33 & 21.46 & 0.727 & $\mathrm{Al}_{2} \mathrm{CeSi}$ \\
\hline & 1 grey & 85.78 & 6.314 & 0.014 & 1.080 & 0.561 & 0.104 & 1.388 & 4.156 & 0.042 & $\mathrm{Al}_{21} \mathrm{Ti}_{2} \mathrm{Ce}$ \\
\hline & 2 grey & 85.40 & 6.228 & 0.015 & 1.410 & 0.650 & 0.087 & 1.431 & 4.134 & 0.055 & $\mathrm{Al}_{21} \mathrm{Ti}_{2} \mathrm{Ce}$ \\
\hline & 3 grey & 84.52 & 6.255 & 0.019 & 1.777 & 0.548 & 0.107 & 1.869 & 4.265 & 0.038 & $\mathrm{Al}_{21} \mathrm{Ti}_{2} \mathrm{Ce}$ \\
\hline & 4 grey & 83.99 & 6.394 & 0.008 & 2.558 & 0.586 & 0.087 & 1.601 & 4.187 & 0.042 & $\mathrm{Al}_{21} \mathrm{Ti}_{2} \mathrm{Ce}$ \\
\hline & 5 grey & 85.53 & 6.377 & 0.015 & 0.946 & 0.544 & 0.100 & 1.659 & 4.272 & 0.042 & $\mathrm{Al}_{21} \mathrm{Ti}_{2} \mathrm{Ce}$ (with traces of $\mathrm{Si}$ and $\mathrm{Cu}$ ) \\
\hline \multirow{11}{*}{$\begin{array}{l}\text { B0 + } 5 \text { wt. } \% \mathrm{La} \\
\text { (with Ti) }\end{array}$} & 1 white & 56.46 & 0.000 & 2.598 & 14.97 & 0.023 & 0.050 & 9.812 & 0.119 & 15.83 & $\mathrm{Al}_{11} \mathrm{La}_{3}(\mathrm{Cu}, \mathrm{Fe})_{4} \mathrm{Si}_{2}$ \\
\hline & 2 white & 59.69 & 0.000 & 2.384 & 14.42 & 0.220 & 0.020 & 9.076 & 0.123 & 13.97 & $\mathrm{Al}_{11} \mathrm{La}_{3}(\mathrm{Cu}, \mathrm{Fe})_{4} \mathrm{Si}_{2}$ \\
\hline & 3 white & 56.64 & 0.000 & 2.942 & 14.43 & 0.036 & 0.031 & 10.12 & 0.080 & 15.61 & $\mathrm{Al}_{11} \mathrm{La}_{3}(\mathrm{Cu}, \mathrm{Fe})_{4} \mathrm{Si}_{2}$ \\
\hline & 4 white & 46.52 & 0.000 & 0.000 & 3.426 & 0.000 & 0.064 & 18.30 & 0.145 & 31.44 & $\mathrm{Al}_{5} \mathrm{La}_{3} \mathrm{Si}_{2}$ \\
\hline & 5 white & 56.33 & 0.000 & 2.686 & 15.70 & 0.067 & 0.058 & 9.508 & 0.120 & 15.45 & $\mathrm{Al}_{6} \mathrm{La}_{2}(\mathrm{Cu}, \mathrm{Fe})_{2} \mathrm{Si}$ \\
\hline & 6 white & 50.39 & 0.000 & 0.000 & 2.654 & 0.061 & 0.099 & 18.09 & 0.093 & 28.52 & $\mathrm{Al}_{3} \mathrm{La}$ (with traces of $\mathrm{Cu}, \mathrm{Si}$, and $\mathrm{Fe}$ ) \\
\hline & 7 white & 84.75 & 7.215 & 0.014 & 0.374 & 2.236 & 0.172 & 0.358 & 0.046 & 4.343 & $\mathrm{Al}_{3} \mathrm{La}$ (with traces of $\mathrm{Cu}, \mathrm{Si}$, and $\mathrm{Fe}$ ) \\
\hline & 8 white & 82.26 & 6.420 & 0.053 & 1.293 & 3.494 & 0.247 & 0.579 & 0.067 & 4.351 & $\mathrm{Al}_{3} \mathrm{La}$ (with traces of $\mathrm{Cu}, \mathrm{Si}$, and $\mathrm{Fe}$ ) \\
\hline & 1 grey & 84.27 & 7.317 & 0.013 & 0.344 & 2.726 & 0.146 & 0.496 & 0.038 & 4.330 & $\mathrm{Al}_{21} \mathrm{Ti}_{2} \mathrm{La}$ (with traces of $\mathrm{Cu}, \mathrm{Si}, \mathrm{Fe}$ ) \\
\hline & 2 grey & 85.22 & 7.428 & 0.009 & 0.258 & 1.983 & 0.090 & 0.333 & 0.075 & 4.320 & $\mathrm{Al}_{21} \mathrm{Ti}_{2} \mathrm{La}$ (with traces of $\mathrm{Cu}, \mathrm{Si}$, and $\mathrm{Fe}$ ) \\
\hline & 3 grey & 84.32 & 7.730 & 0.012 & 0.451 & 2.099 & 0.140 & 0.408 & 0.019 & 4.384 & $\mathrm{Al}_{21} \mathrm{Ti}_{2} \mathrm{La}$ (with traces of $\mathrm{Cu}, \mathrm{Si}$, and $\mathrm{Fe}$ ) \\
\hline \multirow{10}{*}{$\begin{array}{l}\text { B0 + } 5 \text { wt. } \% \\
\text { Ce } \\
\text { (with Ti) }\end{array}$} & 1 white & 42.15 & 0.000 & 0.121 & 1.428 & 0.000 & 0.000 & 22.34 & 33.90 & 0.000 & $\mathrm{Al}_{4} \mathrm{Ce}_{3} \mathrm{Si}_{2}$ \\
\hline & 2 white & 55.71 & 0.000 & 2.833 & 15.79 & 0.000 & 0.008 & 10.00 & 15.64 & 0.000 & $\mathrm{Al}_{11} \mathrm{Ce}_{3}(\mathrm{Cu}, \mathrm{Fe})_{4} \mathrm{Si}_{2}$ \\
\hline & 3 white & 41.46 & 0.522 & 0.105 & 1.367 & 0.000 & 0.032 & 23.12 & 33.33 & 0.000 & $\mathrm{Al}_{4} \mathrm{Ce}_{3} \mathrm{Si}_{2}$ \\
\hline & 4 white & 55.04 & 0.000 & 2.782 & 16.32 & 0.000 & 0.000 & 10.82 & 14.98 & 0.002 & $\mathrm{Al}_{11} \mathrm{Ce}_{3}(\mathrm{Cu}, \mathrm{Fe})_{4} \mathrm{Si}_{2}$ \\
\hline & 5 white & 44.12 & 0.000 & 0.053 & 0.913 & 0.000 & 0.005 & 22.49 & 32.38 & 0.000 & $\mathrm{Al}_{4} \mathrm{Ce}_{3} \mathrm{Si}_{2}$ \\
\hline & 6 white & 85.92 & 8.113 & 0.000 & 0.261 & 0.568 & 0.017 & 0.871 & 4.205 & 0.000 & $\mathrm{Al}_{4} \mathrm{Ce}_{3} \mathrm{Si}_{2}$ \\
\hline & 7 white & 86.83 & 7.153 & 0.010 & 0.327 & 0.820 & 0.018 & 0.515 & 4.247 & 0.000 & $\mathrm{Al}_{4} \mathrm{Ce}_{3} \mathrm{Si}_{2}$ \\
\hline & 1 grey & 87.19 & 7.178 & 0.002 & 0.348 & 0.383 & 0.030 & 0.619 & 4.219 & 0.002 & $\mathrm{Al}_{21} \mathrm{Ti}_{2} \mathrm{Ce}$ (with traces of $\mathrm{Cu}, \mathrm{Fe}, \mathrm{Mg}$, and $\mathrm{Si}$ ) \\
\hline & 2 grey & 87.00 & 7.292 & 0.007 & 0.336 & 0.447 & 0.034 & 0.609 & 4.193 & 0.008 & $\mathrm{Al}_{21} \mathrm{Ti}_{2} \mathrm{Ce}$ (with traces of $\mathrm{Cu}, \mathrm{Fe}, \mathrm{Mg}$, and $\mathrm{Si}$ ) \\
\hline & 3 grey & 86.75 & 7.256 & 0.019 & 0.427 & 0.441 & 0.018 & 0.810 & 4.241 & 0.000 & $\mathrm{Al}_{21} \mathrm{Ti}_{2} \mathrm{Ce}$ (with traces of $\mathrm{Cu}, \mathrm{Fe}, \mathrm{Mg}$, and $\mathrm{Si}$ ) \\
\hline
\end{tabular}

illustrate the distribution of $\mathrm{Ce}$ and $\mathrm{La}$ in the gray-phase particles compared to $\mathrm{Ti}$ and $\mathrm{Si}$. From these figures, it is evident that $\mathrm{Ti}$ is the main element in the gray phase, with traces of RE and Si. Figure 11 shows the distribution of $\mathrm{La}$ and $\mathrm{Ti}$ in such particles observed in the $\mathrm{D} 0+\mathrm{La}+\mathrm{Ti}$ alloy sample.

Another interesting observation made is the interaction between the RE and transition metals, in particular 
$\mathrm{Cu}$ and Fe. Figure 12 shows the interaction between $\mathrm{La}$ and $\mathrm{Cu}$ in the D0 alloy containing $0.15 \% \mathrm{Ti}$. Lanthanum platelets seem to attract $\mathrm{Cu}$ at their edges as shown in Figure 12(b) which is an enlarged portion of Figure 12(a). On the other hand, it is evident that neither $\mathrm{Cu}$ nor Si exhibits an affinity to react with the gray phase. Considering the white phase, observed in Figures 13 and 14, $\mathrm{Cu}$ has a relatively higher affinity to react with $\mathrm{La}$ compared to $\mathrm{Fe}$ as inferred from their relative intensities and the size of their corresponding peaks in Figure 13(b). It should be borne in mind that the white platelets are very thin (less than $1.5 \mathrm{~nm}$ thick) which would explain the variation in their composition (the diameter of the area examined by the electron beam is $\sim 3 \mu \mathrm{m}$ ). Based on these observations, it would be reasonable to say that the gray phase (due to its larger size) would exhibit a definite composition overall, whereas the composition of the white phase would vary from one particle to another.

Table 2 summarizes the WDS analysis carried out on the phases observed in the present alloys. The composition of the gray phase could be written as $\mathrm{Al}_{21} \mathrm{Ti}_{2} \mathrm{RE}(\mathrm{RE}=\mathrm{La}$ or $\mathrm{Ce})$. The white phase has several compositions caused by its reactivity with the other elements in the matrix, particularly $\mathrm{Si}, \mathrm{Cu}$, and Fe. The phases formed in the alloys investigated are as follows:

(1) B0 (low Si)-La-containing alloy: $\mathrm{Al}_{11} \mathrm{La}_{3}(\mathrm{Cu}, \mathrm{Fe})_{4} \mathrm{Si}_{2}$, $\mathrm{Al}_{5} \mathrm{La}_{3} \mathrm{Si}_{2}, \mathrm{Al}_{6} \mathrm{La}_{2}(\mathrm{Cu}, \mathrm{Fe})_{2} \mathrm{Si}$, and $\mathrm{Al}_{3} \mathrm{La}$

(2) D0 (high Si)-La-containing alloy: $\mathrm{AlLaSi}, \mathrm{Al}_{2} \mathrm{LaSi}$, and $\mathrm{Al}_{9} \mathrm{La}_{4} \mathrm{Cu}_{2} \mathrm{Si}_{4}$

(3) B0-Ce alloy: $\mathrm{Al}_{4} \mathrm{Ce}_{3} \mathrm{Si}_{2}$ and $\mathrm{Al}_{11} \mathrm{Ce}_{3}(\mathrm{Cu}, \mathrm{Fe})_{4} \mathrm{Si}_{2}$

(4) D0-Ce-containing alloy: $\mathrm{Al}_{2} \mathrm{CeSi}$

\section{Concluding Remarks}

Based on the results obtained in the present study, the following remarks may be highlighted. Addition of a fairly large amount of RE metals ( $\mathrm{La}$ or $\mathrm{Ce}$ ) leads to the appearance of several peaks in the solidification curve between the primary $\alpha$ - $\mathrm{Al}$ and $\left(\mathrm{Al}-\mathrm{Al}_{2} \mathrm{Cu}\right)$ eutectic phases. Although a significant drop in the eutectic temperature is caused by the addition of $5 \% \mathrm{La}$ or $\mathrm{Ce}$, the corresponding modification of the eutectic $\mathrm{Si}$ is marginal. Two main categories of intermetallics were documented: a gray phase in the form of sludge with a fixed composition and a white phase in the shape of thin platelets. Due to the high affinity of RE to react with $\mathrm{Si}, \mathrm{Fe}$, and $\mathrm{Cu}$, several compositions were obtained explaining the observed multiple peaks in the solidification curve. Judging by the morphology of the gray phase, it is assumed that this phase was precipitated in the liquid state and acted as a nucleation site for the white phase. Both La and Ce are substitutable.

\section{Conflicts of Interest}

The authors declare that they have no conflicts of interest.

\section{Acknowledgments}

The authors would like to thank Amal Samuel for enhancing the quality of the images used in the present article.

\section{References}

[1] Y. Tsai, S. Lee, and C. Lin, "Effect of trace Ce addition on the microstructures and mechanical properties of A356 (Al-7Si$0.35 \mathrm{Mg}$ ) aluminum alloys," Journal of the Chinese Institute of Engineers, vol. 34, no. 5, pp. 609-616, 2011.

[2] E. M. Elgallad, H. W. Doty, S. A. Alkahtani, and F. H. Samuel, "Effects of $\mathrm{La}$ and $\mathrm{Ce}$ addition on the modification of $\mathrm{Al}-\mathrm{Si}$ based alloys," Advances in Materials Science and Engineering, vol. 2016, Article ID 5027243, 13 pages, 2016.

[3] A. M. Nabawy, A. M. Samuel, S. A. Alkahtani, K. A. Abuhasel, and F. H. Samuel, "Role of cerium, lanthanum, and strontium additions in an $\mathrm{Al}-\mathrm{Si}-\mathrm{Mg}$ (A356) alloy," International Journal of Materials Research, vol. 107, no. 5, pp. 446-458, 2016.

[4] Y. Tsai, C. Chou, R. Jeng, S. Lee, and C. Lin, "Effect of rare earth elements addition on microstructures and mechanical properties of A356 alloy," International Journal of Cast Metals Research, vol. 24, no. 2, pp. 83-87, 2011.

[5] O. Elsebaie, F. H. Samuel, and S. Al kahtani, "Intermetallic phases observed in non-modified and Sr modified Al-Si cast alloys," International Journal of Cast Metals Research, vol. 26, no. 1, pp. 1-15, 2013.

[6] S. L. Joy Yii, N. M. Anas, M. N. Ramdziah, and A. S. Anasyida, "Microstructural and mechanical properties of $\mathrm{Al}-20 \% \mathrm{Si}$ containing Cerium," Procedia Chemistry, vol. 19, pp. 304-310, 2016.

[7] H. Yi and D. Zhang, "Modification effect of pure rare earth metal La in as cast Al-17\%Si alloys," Transactions of Nonferrous Metals Society of China, vol. 13, no. 2, pp. 258-364, 2003.

[8] M. Hosseinifar, Physical Metallurgy and Thermodynamics of Aluminum Alloys Containing Cerium and Lanthanum, Ph.D. thesis, McMaster University, Hamilton, Canada, 2009.

[9] L. Bäckerud, G. Chai, and J. Tamminen, Solidification Characteristics of Aluminum Alloys, Vol. 2, American Foundry Society, Schaumburg, IL, USA, 1990.

[10] R. D. Shull and A. Joshi, Thermal Analysis in Metallurgy, TMS, Warrendale, PA, USA, 1992.

[11] H. Biloni and W. J. Boettinger, "Solidification," in Physical Metallurgy, R. W. Cahn and P. Haasen, Eds., pp. 669-842, North Holland, Amsterdam, Netherlands, 4th edition, 1996.

[12] R. Colás, E. Velasco, and S. Valtierra, "Castings," in Handbook of Aluminum: Physical Metallurgy and Processes, G. E. Totten and D. S. MacKenzie, Eds., pp. 591-641, M. Dekker, New York, NY, USA, 2003.

[13] J. Hernandez-Sandoval, A. M. Samuel, S. Valtierra, and F. H. Samuel, "Thermal analysis for detection of Zr-rich phases in $\mathrm{Al}-\mathrm{Si}-\mathrm{Cu}-\mathrm{Mg}$ 354-type alloys," International Journal of Metalcasting, vol. 11, no. 3, pp. 428-439, 2016.

[14] B. Golbahar, E. Samuel, A. M. Samuel, H. W. Doty, and F. H. Samuel, "On thermal analysis, macrostructure and microstructure of grain refined $\mathrm{Al}-\mathrm{Si}-\mathrm{Mg}$ cast alloys: role of $\mathrm{Sr}$ addition," International Journal of Cast Metals Research, vol. 27, no. 5, pp. 257-266, 2014.

[15] E. A. Elgallad, S. A. Alkahtani, H. W. Doty, and F. H. Samuel, "On the mechanical properties and fracture characteristics of Al-2\%Cu based cast alloys," International Journal of Materials Science and Engineering, vol. 6, pp. 15-34, 2016.

[16] K. Nogita, S. D. McDonald, and A. K. Dahle, "Eutectic modification of Al-Si alloys with rare earth metals," Materials Transactions, vol. 45, no. 2, pp. 323-326, 2004.

[17] S. A. Alkahtani, E. M. Elgallad, M. M. Tash, A. M. Samuel, and F. H. Samuel, "Effect of rare earth metals on the microstructure of Al-Si based alloys," Materials, vol. 9, no. 12, p. 45, 2016. 


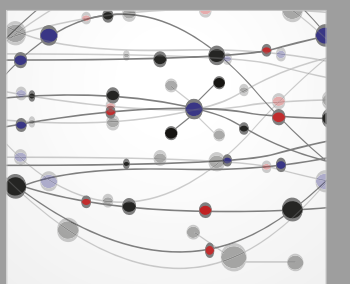

The Scientific World Journal
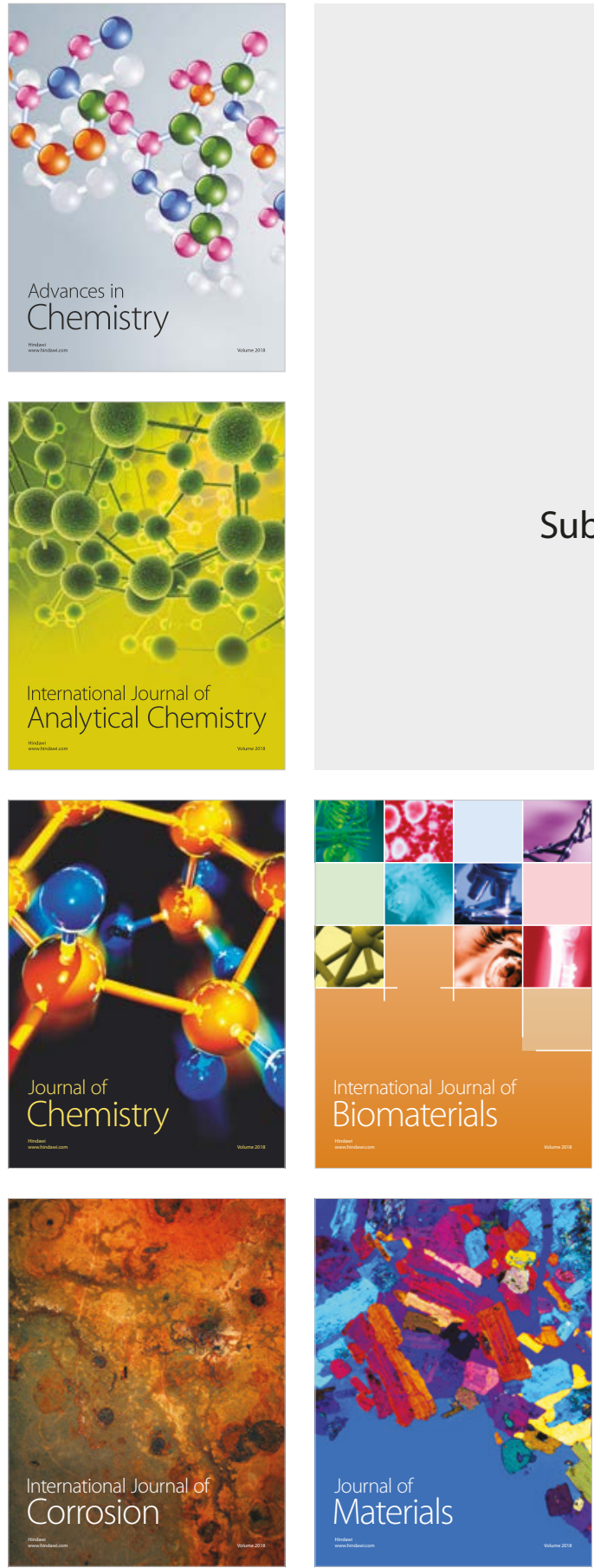

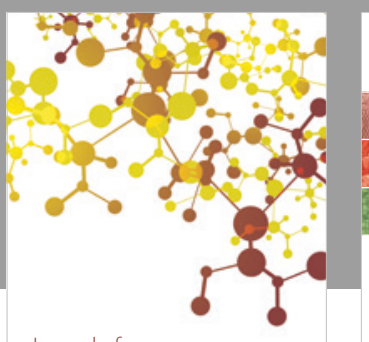

Journal of

Applied Chemistry
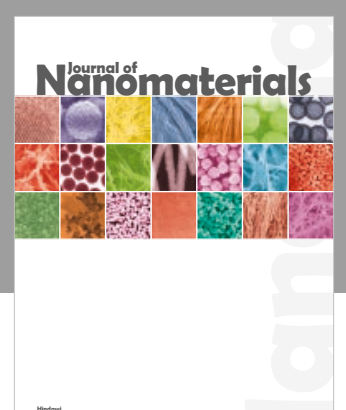

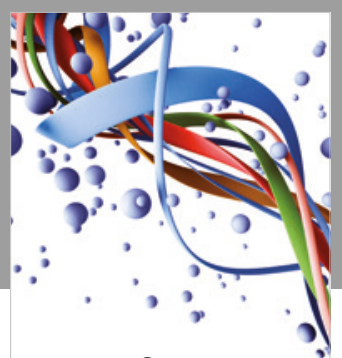

Scientifica

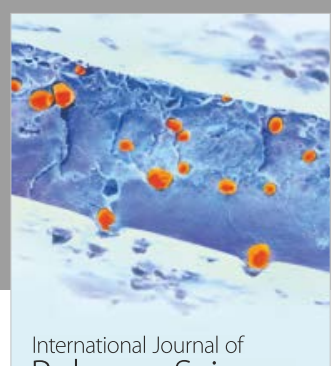

Polymer Science

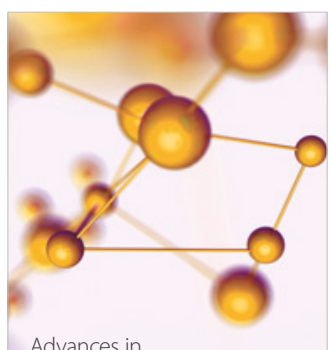

Physical Chemistry
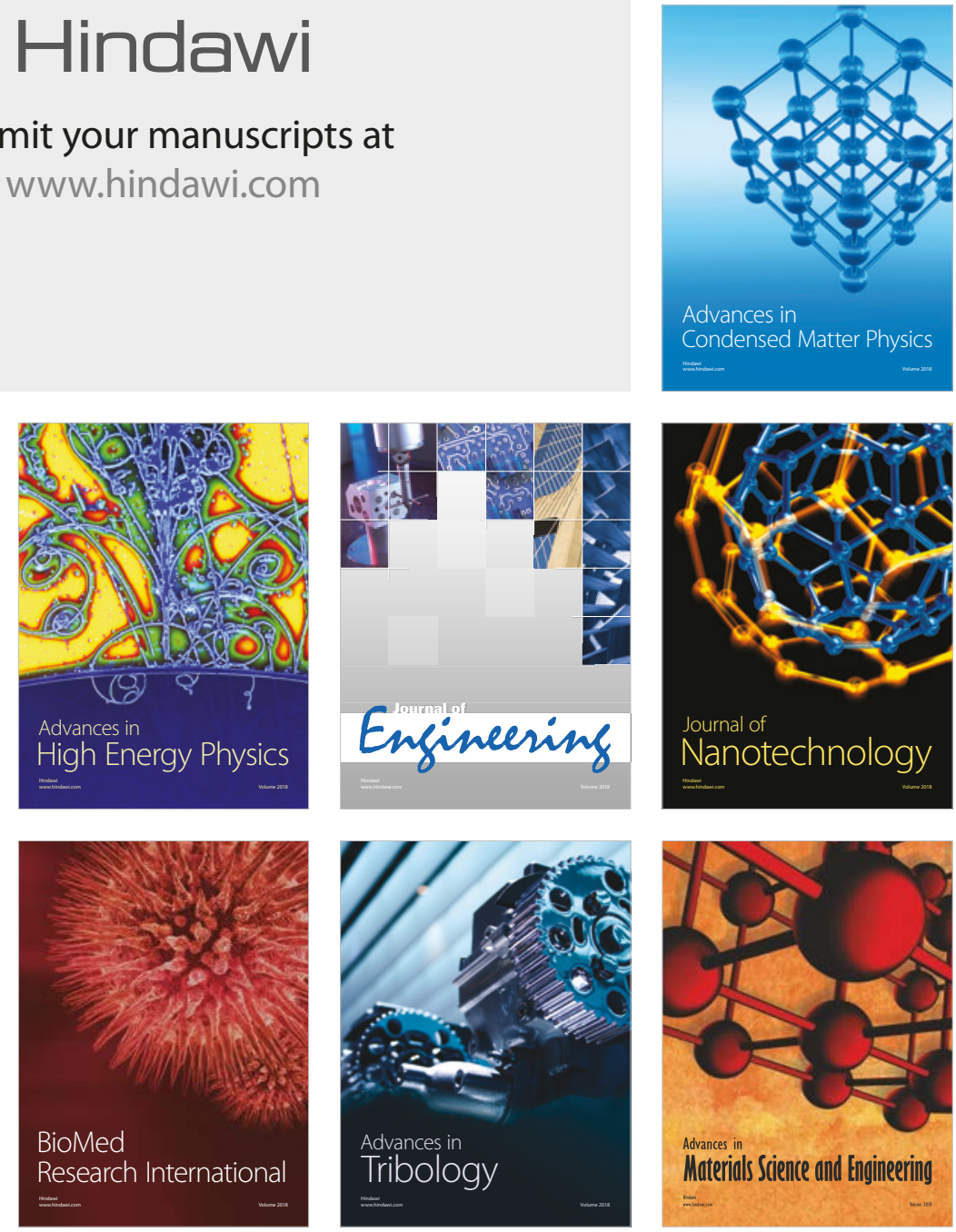